\title{
The "Place" of Religion in the Italian Asylum Seekers' Reception System: Constitutional, Legislative and Procedural Framework
}

\author{
Paolo Bonetti
}

\author{
Religion in the Italian Constitutional System: Every (Italian or \\ Foreign) Person's Right to Religious Freedom
}

Forced migrations lead foreigners to come into contact with the Italian legal system, which is person-based, as well as built on the principles of democracy, pluralism and secularism, and in which religion plays an open role and has an open discipline, often shaped by very different criteria than those existing in the countries of origin and transit.

In the Italian constitutional system, the religious phenomenon is part of a social dynamic that must be recognized, respected and supported by public authorities through "negative" and "positive" guarantees: exercising religious freedom contributes to the "full development of the human person" (art. 3, par. 2 of the Constitution) and to the "spiritual progress of society" (art. 4, par. 2 of the Constitution) (Troilo, 2008).

Furthermore, the historically predominant presence of Catholics and the presence, on the Italian territory, of the Vatican City State (state entity established in 1929 thanks to the Lateran Pacts and in which the Holy See -i.e. the supreme authority governing the whole Catholic Church- is located) have caused religion in Italy to be perceived differently than in the other States (Ravà, 1963), and have facilitated the preservation of the de facto dominant character of the Catholic Church (Botta, 2002).

Indeed, sometimes foreigners enter the Italian territory to participate in the functioning of the central bodies of the Catholic Church (for this purpose, they enjoy free access and a special treatment, as established by the 1929 Treaty between Italy and the Holy See) and the number of foreigners arriving and staying in the Italian State for religious reasons are much higher than in other States. The same provisions concerning immigration and the status of foreign nationals (Legislative Decree no. 286/1998) provide for a specific entry visa for religious reasons (which allows entry to religious people and foreign religious ministers belonging to denominational organizations and who intend to 
participate in religious events or exercise ecclesiastical, religious or pastoral activity), regulate stays for religious reasons and the right to maintain or regain family unity for holders of this kind of residence permit.

The constitutional principle of equality, established by art. 3 of the Constitution, also applies to foreigners as regards the ownership of the fundamental rights guaranteed to every person by art. 2 of the Constitution. Among the latter, the right to religious freedom is certainly included, regardless of citizenship status (Grosso, 1999; Pistan, 2013; Olivetti, 2018; Curreri, 2018) and is one of the fundamental rights guaranteed to all foreigners present in Italy, also in compliance with the already cited Legislative Decree no. 286/1998. Art. 19 of the Constitution acknowledges the right to freely profess one's religious faith and to exercise it in any form, individually or with others, in private and in public, through rites not offensive to the accepted principles of public morality.

Hence it follows that the religious freedom is guaranteed to all foreigners, including asylum seekers, both during and after the administrative and judicial procedure examining their applications. Moreover, foreigners who are prevented from the actual exercise of these rights in their country of origin are entitled to apply for asylum according to art. 10, par. 3 of the Constitution as enforced by the current legislation. More precisely, art. 19 of the Italian Constitution guarantees three faculties pertaining to religious freedom.

The first is the freedom to profess one's own religion. This entails the freedom to declare publicly, either through words or deeds, (or even not to be forced to declare) one's own religious faith, as well as the very freedom to choose to follow one religion first, and then opt for another; or the freedom not to follow any religion or even to stop following it; ${ }^{1}$ or, more generally, the right not to be forced to behave in a religious way (Musselli, 1994), with no punitive, discriminatory or persecutory consequences, on both the regulatory and the social level. The refusal or the claim to adopt behaviors that are forbidden or imposed by one's own belief are in fact considered as actual acts of profession (Ricca, 2006). In this respect, freedom of religion also includes the right to conform one's life to the indispensable dictates of one's own conscience, thus respecting the fundamental rights recognized to other people as well as the constitutional duties.

Besides, the freedom to profess one's own religion implies -and implicitly presupposes- the faculty of shaping one's own personal idea regarding religious matters and the faculty of adhering to, or not adhering to, a particular religious doctrine. Thus, the Constitutional Court affirmed that freedom of

1 See Constitutional Court, sentence no. 239/1984. 
conscience, referring to the profession of both one's religious faith and of one's opinion in religious matters, is included in the guarantee of art. 19 of the Constitution and must also be included among the inviolable rights of man. ${ }^{2}$

The Italian legal system, which is based on personalist and pluralist principles, cannot remain indifferent to the cases of conscientious objection for religious reasons. Indeed, it has responded by repealing the obligations that were objected to, transforming them into mere faculties or allowing exemptions from them by providing alternative forms of services (for example, civil service as an alternative to the enrolment in the armed or police forces in times of war or serious international crisis). Moreover, the law recognizes forms of conscientious objection to abortive practices and medically assisted procreation (laws no. 194/1978 and no. 40/2004), as well as to animal testing carried out by doctors, researchers and students (law no. 413/1993).

The Italian constitutional system presupposes that "the development of the individual conscience as far as religious matters are concerned (whatever the final decisions are) is part of a more general spiritual and intellectual maturation of the person. Thus, denying or reducing the autonomy of this process of maturation means to deny or prevent the development of the person as such" (Cardia, 1998; Bellini, 1973).

Religious freedom is a perfect subjective right, which can be enforced, within the limits set by the juridical system, in relation to any subject, either public or private, and in any social context or relationship, exactly as all the rights pertaining to freedom: it is, therefore, an inviolable and fundamental right, which does not allow for any repression or restriction by any public administrations. ${ }^{3}$

However, religious freedom is not without limitations, as every fundamental right can be restricted by other principles and precepts expressly stated or deriving from the Constitution, ${ }^{4}$ and must therefore be exercised so as not to damage other fundamental rights, both one's own and others' (e.g. personal freedom, freedom of domicile, of communicating privately, of circulation, of residence, of manifestation of thought, of association, of peaceful and unarmed assembly, of trade union and political party organization, of property rights and private economic initiative, and of active and passive electorate) and in order to fulfil constitutional obligations (i.e. economic, political and social solidarity, defending one's homeland, observing the Constitution and

2 See Constitutional Court, sentences no. 14/1973, no. 117/1979, no. 239/1984.

3 See Cassation Court in joint sessions, 18 November 1997, no. 11432, in Quad. dir. e pol. eccl., 6, 1998, p. 736 .

4 Constitutional Court, sentence no. 100/1981. 
the laws, paying taxes, studying, educating and financially supporting one's children).

Religious freedom also includes the right to leave or change one's religious group. This is relevant also in relation to the legal status of foreigners already present in Italy, also to obtain the right to asylum, when in the country of origin such conversion might cause persecutions or discriminations. In fact, it allows the foreigner to be granted the status of refugee sur place, in compliance with art. 4 of Legislative Decree no. 251/2007, especially if the conversion is manifested in Italy, but originally happened in the country of origin, without having been manifested in that country for the well-founded fear of being punished.

The conversion of anyone, Italian or foreigner, to a different religion cannot entail any sanction, not even by the abandoned religious confession, so that any impediment to cultivate normal relationships with one's relatives and to use means of communication to prevent the conversion to, or the abandonment of, a religious confession (when it does not integrate the criminal offence of kidnapping or private violence) violate the fundamental rights of freedom of the person, who is given the right to perform the activities necessary for the full restoration of the freedom, either directly or by contacting the judicial or the public security authority. Then, in the event that people within an authoritarian religious structure may lose their autonomous decision-making capacity, either their relatives or the public prosecutor could ask for judicial measures with the aim to ascertain that they are not withheld against their will and that they are not the victim of undue external pressure to remain in the group (Musselli, 1994).

The religious freedom illustrated so far leads at least to four consequences, identified by the doctrine (Cardia, 2010), some of which may have significant relevance for the foreigner, including the asylum seeker:

a) the juridical irrelevance of both the confessional belonging and the religious beliefs of citizens in their public and social life;

b) the right to keep their religious affiliation and their religious convictions confidential;

c) the prohibition of imposing any confessional behavior on people;

d) the prohibition to investigate the personal religious orientation.

In this regard, it is worth looking more closely at the consolidated aspect of Italian jurisprudence and doctrine according to which confessional belonging, sentiments, opinions, and the behavior of people which are the direct expression of religious feelings or inner convictions are protected by a general principle of confidentiality, based on art. 2 and 19 of the Constitution.

This aspect significantly affects the evaluation of the asylum applications that are based on an impediment to the effective exercise of religious freedom. 
Said applications cannot be assessed by asking the foreigner to prove his or her religious affiliation or to fully understand the dogmas and the acts of worship of the professed religion, nor can they be rejected for the mere circumstance that, in the country of origin, the applicant did not state his/her religious affiliation or religious conversion in order to avoid negative consequences. In the Italian constitutional system these principles are implicit; on the other hand, these same principles have already been affirmed by the Court of Justice of the European Union in examining the applications for the recognition of international protection (Chapter 4).

The second faculty included in religious freedom is the right to promote one's own religion, which comprises the right to spread information and knowledge among others in order to make them appreciate the religion and to try to convert them - this, however, does not stand for conversion practices that undermine the fundamental rights of the converts, i.e. if they are not aware of it, if the conversion involves the use of force, or if it compromises the others' personal integrity, health, and private property (Ricca, 2006).

The right to religious propaganda has some limits, since it must be exercised in such a way as to respect:

a) the rights of others, so that, for example, no type of religious propaganda legitimizes the violation of a person's domicile or his/her right to rest (when the person is disturbed by songs, calls to prayer or ringing of bells);

b) the rules governing the means by which propaganda is implemented (for example, the press, radio and television broadcasting, etc.);

c) the religious freedom of others and also the religious sentiment towards other religions, so that it cannot be exercised through useless contumely which offends the believer (and therefore his/her personality) and insults the ethical values on which the religious phenomenon is based. ${ }^{5}$

After many sentences of the Constitutional Court, the criminal legislation regarding the offenses against religious sentiment has been reformulated by law no. 85/2006, which ensures an equal protection of all religious confessions from the above-mentioned offenses.

The right to religious propaganda includes presenting one's message in a way that turns out to be attractive, but, at the same time, does not allow any mystification - i.e. a manner that prevents the recipient of the propaganda from correctly perceiving the aims of the religious group (Musselli, 1994; Finocchiaro, 1990).

The constitutional protection of the freedom to profess and promote one's religion is relevant both for the reception standards of the asylum seekers

5 Constitutional Court, sentence no. 188/1975. 
(which will be examined further below), and for the legal qualification of the actual danger to the security of the State deriving from the manifestation of any religious ideas. In particular, the administrative measure for expulsion ordered by the Minister of the Interior on grounds of public and state security, pursuant to art. 13, par. 1 of Legislative Decree no. 286/1998, cannot be applied in the event of mere manifestations of religious ideas, even in the case of Islamic religious fundamentalism, and must instead refer to behaviors that are likely to create an actual danger to public order and to the security of the State (art. 159 of Legislative Decree no. 112/1998).

Indeed, the jurisprudence, faced with a ministerial expulsion based only on declarations made by the foreigner to the press and considered as "simple manifestations of the thought that, because of the blatant ways in which they have been expressed, objectively appear to be incompatible with the will to cause any real damage to anyone", has affirmed that "the need to protect the fundamental good represented by the preservation of the bases of the system that guarantees the orderly development of the entire social life can legitimately involve the compression of other constitutional values" and has therefore expressed the principle of law according to which "the faculties protected directly by the Constitution (such as the expression of thought) can be administratively compressed only if their exercise has proved to be of concrete danger to society". ${ }^{6}$ On the contrary, the ministerial expulsion is considered legitimate if it is not only based on an explicit adherence to Islamic fundamentalism, but also on the participation in activities of propaganda or of dissemination of material to incite religious violence in Italy or abroad. ${ }^{7}$

The third faculty consists in the freedom of worship, both in private and in public, excluding rites contrary to public morality. This freedom is manifested when performing ritual activities in private or public places, without requiring any authorization from the public authorities ${ }^{8}$ and without the prior notice to the authorities required by art. 17 of the Constitution for meetings in public places. ${ }^{9}$ It also entails the right not to participate in religious rites (Curreri, 2018). In fact, religious freedom generally excludes any imposition by the state legal system, even when the act of worship belongs to the confession professed by the one to whom it is imposed, because the State does not have to interfere in an "order" that does not belong to it, except for the aims and in the cases

6 Lazio Regional Administrative Court, headquartered in Rome, Section I ter, sentence 11 November 2004, no. 15336.

7 See Council of State, Section vi, no. 88/2006.

8 See Constitutional Court, sentence no. 59/1958.

9 See Constitutional Court, sentence no. 45/1957. 
expressly mentioned by the Constitution..$^{10}$ Thus, it is not only a matter of conscience for non-believers, since they cannot be obliged to perform acts whose meaning goes against their convictions. The very nature of being religious is at stake, and, in the civil order, said nature can only be a manifestation of freedom. ${ }^{11}$ While implementing this principle, the Constitutional Court, with the sentence no. 149/1995 and other rulings, has played an important role on the legislation concerning the oath in the civil trial, which no longer contains appeals to the deity. Similarly, with regard to the criminal trial, the legislator intervened directly when the new criminal procedure code was issued.

Moreover, the public worship of one's religion also entails the need to have free access to places where it is possible to perform cult activities and to open new places of worship not because there is a social right to have a place of worship, but because the State does promote its establishment, in compliance with both the rules on land management and of those concerning safety. ${ }^{12}$ The only rituals that are not admitted are those against public morality, which the doctrine identifies with the common sense of decency. Therefore, rituals involving sexual or orgiastic activities are considered to be against public morality, as well as practices causing a general sense of repugnance and disgust on the basis of a common ethical sentiment, such as particular initiation ceremonies (Mortati, 1976; Musselli, 1994) - which includes, in the prohibition, the "practices of worship that, due to their violent and aggressive nature, may be reprehensible to the human conscience" (Lillo, 2006).

Freedom of worship must also be exercised in accordance with the rights and freedoms of others. Ritual practices that damage life or personal liberty, and that therefore involve permanent damage to the physical integrity of consenting people (e.g. female genital mutilation), as well as practices that damage the life or the physical integrity of animals are in fact unlawful. In particular, art. 583-bis of the Penal Code defines as a crime, punished by imprisonment from 4 to 12 years, "clitoridectomy, excision, infibulation and every other practice that produces effects of the same type". Besides, art. 544-bis and 544-ter punish anyone who, "out of cruelty or without necessity", kills or injures an animal, or subjects it to torture or distress (even during shows and events). On the contrary, the ritual slaughter of animals (halal for Muslims and kosher for Jews) is allowed by derogatory provisions of the Ministry of Health, and must be carried out in authorized facilities and under the supervision of local health authorities.

10 See Constitutional Court, sentence no. 85/1963.

11 See Constitutional Court, sentence no. 334/1996.

12 See Constitutional Court, sentence no. 63/2016. 


\section{The Right to Asylum of the Foreign Nationals Who are Prevented from Actually Exercising Religious Freedom}

Art. 10, par. 3 of the Italian Constitution provides that foreign nationals who, in their own countries, are denied the freedoms guaranteed by the Italian Constitution, have the right to asylum in the Italian territory under the conditions established by law. Since religious freedom and the non-discrimination principle towards any religion are provided for by the Italian Constitution, foreigners who have a well-founded fear of being persecuted for religious reasons should enjoy the right to asylum. They should do so in one of the three forms provided for by the existing laws, in compliance with international and European standards (Legislative Decree no. 251/2007 and no. 25/2008). Such forms are the following: $a$ ) the refugee status (providing a 5-year residence permit, automatically renewable upon expiry); $b$ ) the status of subsidiary protection (providing a 5-year residence permit, renewable upon expiry and if the situation persists) for those who cannot be granted the refugee status, but who are afraid of suffering physical harm because of death penalty threats, inhuman and degrading treatments, tortures, and possible violence against civilians in situations of internal or international conflict; $c$ ) the special protection (providing a 1-year permit, renewable as long as the situation persists) for those who cannot obtain the refugee status or the subsidiary protection, but cannot be expelled because of the chance of persecution or torture in either the origin or the sending country. This last permit has partially replaced the previous residence permit for humanitarian reasons repealed by Decree Law no. 113/2018 and which used to be issued to those who could not be removed for humanitarian reasons also deriving from constitutional or international obligations.

Legislative Decree no. 251/2007, in order to enforce the EU directive on international protection (see Chapter 4), defines as "refugee" the foreign national who, owing to the well-founded fear of being persecuted for reasons of race, religion, nationality, membership of a particular social group or political opinion, is outside the country of nationality and is unable or -owing to such fearis unwilling to avail himself or herself of protection of that country, or a stateless person, who is outside the territory of former habitual residence and is unable or is unwilling to return to it for the same reasons as mentioned above, without prejudice to the causes of exclusion pursuant to art. 10 of Legislative Decree no. 251/2007. In order to grant the refugee status, the acts of persecution must be a serious violation of fundamental human rights, including religious freedom. This is violated when it is reduced to freedom of worship alone, or to worship only in certain places, when it is impeded or sanctioned the freedom to profess or to propagandize (thus prohibiting and punishing any form 
of proselytizing or of missionary activity) or to belong or to convert to a particular religion.

However, the refugee status can be granted only if the violation of rights is serious. In fact, when a State guarantee a special condition for a specific religion, there is no persecution if the lives of the believers of other religions are substantially normal. Besides, as of December 2018, protection against religious persecutions may be less effective because -in compliance with the EU directive- the application for international protection in the Italian legal system must be rejected when "in a part of the country of origin, the applicant either has no well-founded fear of being persecuted or is not at real risk of suffering serious harm, or has access to protection against persecution or serious harm, and he/she can legally and safely travel to and gain admittance to that part of the country and can reasonably be expected to settle there" (art. 30, par. 1 of Legislative Decree no. 25/2008). Such notion turns out to be hardly effective if applied to the situation of multi-religious or federal States in which interreligious conflicts are very serious and the legislation of each federated State can adopt the model of confessionalism and religious discrimination.

In order to recognize the refugee status, acts of persecution or lack of protection against such acts must be connected to the reasons indicated by art. 8 of Legislative Decree no. 251/2007, among which is "religion" itself, which includes theistic, non-theist and atheist convictions, participation in, or abstention from, rituals of worship celebrated in private or in public, both individually and in community, other religious acts or professions of faith, as well as the forms of personal or social behavior based on a religious belief or prescribed by it.

It is therefore not necessary to prove that the personal or social behavior that has been persecuted has a strictly religious character. As a result, if in a particular country there are policies specifically implemented to contrast certain religions or certain religious currents of thought (e.g. Islamic fundamentalism) through measures to combat terrorism or conducts against social peace, acts of persecution for religious reasons may occur. For example, they may happen against women who wear the veil in public, without having to demonstrate the anti-Islamic orientation of said political measures, nor the existence of a real intrinsically religious character of that social behavior, e.g. of the veil as prescribed by Islam, since a link with this religion based on experience is sufficient (Codini, 2009). Moreover, there is no persecution for religious reasons if ritual murders are prohibited, as well as any incitement to violence or to any common crimes committed for religious reasons.

Furthermore, there is actual religious persecution even if the religious affiliation of the person or his/her religious acts have erroneously been presupposed 
by the persecutor. In fact, in examining whether an applicant has a wellfounded fear of being persecuted, it is irrelevant that the person actually possesses the racial, religious, national, social or political characteristics that provoke the acts of persecution, as long as said characteristic is attributed to the persecuted person by the author of the persecutions (art. 8 of Legislative Decree no. 251/2007). In practice, for example, the Gorizia Territorial Commission recognized the religious persecution of an Eritrean woman raped in prison while pregnant and forced to have an abortion because of the violence suffered after being accused of belonging to the Pentecostal Christian faith without any evidence (Benvenuti, 2011).

Besides incorporating the EU directive on international protection qualifications (Chapter 4), these legislative norms seem to take over the three notions of religion indicated in the UNHCR guidelines:

a) religion seen as a belief;

b) religion seen as identity;

c) religion as a lifestyle.

The Court of Cassation granted the refugee status to a foreigner who fled his country for reasons connected to religious persecutions, even if said applicant had provided no evidence whatsoever - and that was because the persecution had been attested by documentation from governmental and nongovernmental organizations. ${ }^{13}$

Nevertheless, religious persecutions usually affect the right to freedom of religion (for example by prohibiting the worship of certain cults or confessions), as well as other rights, for example by providing for different legal treatment basing on whether one is or is not a member of a particular religion. ${ }^{14}$

Indeed, religious persecution can take different forms. For instance, the prohibition of being part of a religious community or of celebrating the cult in public or in private, the adoption of discriminatory measures against a specific confession, forced conversions (Abu Salem, Fiorita, 2016) or impeded conversions towards religions that are not recognized by the authorities.

During the examination of the applications, in cases of persecution for religious reasons, the personal interview plays a significant role, especially when the reasons behind the persecution are, for example, a conversion to a religion that was not manifested in the country of origin. When there is no supporting

13 Court of Cassation I, sentence no. 26056, 1 December 2010.

14 La tutela dei richiedenti asilo - Manuale giuridico per l'operatore, curated by UNHCR, ASGI, Central service of the SPRAR, 2016, p. 16 (http://www.unhcr.it/wp-content/uploads/ 2016/o1/1UNHCR_manuale_operatore.pdf). 
evidence of the persecutions, the interview has to focus on the details of the conversion, on the contents of the religion that the applicant wants to profess, on the methods of prayer and on all the other elements that prove that his/her statements are well-founded. To this end, information on the punishment imposed, in the country of origin, in the event of a conversion appears to be useful (Benvenuti, 2011).

Besides, it is difficult to provide evidence demonstrating the persecution and regarding the agents of persecution. According to art. 3 of Legislative Decree no. 251/2007, while examining the application, in addition to the declarations and the documentation presented by the applicant, one must also take into consideration the facts concerning the country of origin and the personal situation of the applicant. In fact, it is important to collect information on the countries of origin through the various databases (including the ones managed by EASO, by UNHCR, and by the National Commission for the right to asylum) even though it is not sufficient.

Judges, in fact, usually nullify the reject of the applications decided by the territorial commissions, especially when they are based on the non-credibility of the applicants, in virtue of art. 3, par. 5 of Legislative Decree no. 251/2007. In compliance with the EU directive, it states that "where some elements or aspects of the statements of the applicant for international protection are not supported by evidence, said elements shall be considered to be truthful if the competent authority recognizes that:

a) the applicant has made all reasonable efforts to substantiate the application;

b) all relevant elements at the applicant's disposal have been submitted, and a satisfactory explanation regarding any lack of other relevant elements has been given;

c) the applicant's statements are found to be coherent and plausible and do not run counter to available specific and general information relevant to his/her case;

d) the applicant has applied for international protection at the earliest possible time, unless he/she can demonstrate good reason for not having done so;

e) the general credibility of the applicant has been established".

Fundamentally, because of the principle of good faith, asylum seekers do not have the burden of proving irrefutably their claims - which would be extremely difficult to fulfill after escaping from persecution or from a conflict, and which would nullify the right to asylum. Any elements of the narration expressed by the applicant, even if not proven, are considered as credible if the circumstances indicated in the article are present. 
In this regard, the Court of Cassation makes it mandatory for those who examine the applications to cooperate to ascertain the facts, after having heard the declarations of the foreigner and even if these are incomplete or apparently contradictory. More precisely, the Court of Cassation ${ }^{15}$ has decided that the statements that are intrinsically unreliable based on the indicators of subjective authenticity contained in art. 3 of Legislative Decree no. 251/2007, do not require an informal in-depth investigation, when the lack of truthfulness does not derive exclusively from the impossibility of providing evidence on the objective situation from which the described situation of risk arises or when the narration is about strictly interpersonal episodes of violence. Furthermore, the description of a life-threatening situation deriving from unwritten rules imposed with violence towards a gender, a social or religious group, or even an enemy family group (e.g. tribal rules), when it is tolerated or tacitly approved by state authorities, does require an informal in-depth investigation in order to verify the degree of diffusion and impunity of the violent behavior described, as well as the response of state authorities. To sum it up, the assessment of the unreliability of the foreigner's statements cannot be based only on his/her impossibility to provide evidence, as it is formally necessary to evaluate if the representation of situations that allow for subsidiary protection is true in the current situation of the country of origin. ${ }^{16}$

Moreover, the Court of Cassation specified in sentence no. 5224 of 2013 that the presence of a credible version of the facts causing possible life-threatening situations in case of return to the homeland is the necessary condition for the competent judicial body to start an investigation. Therefore, even if the conformity of the documents produced by the applicant with the original ones and the substantial credibility of his/her statements are disputed, the traditional principle of the ordinary civil proceedings does not apply. Indeed, the judge -except in the case of procedural impediments- has the duty to cooperate in ascertaining the relevant facts by carrying out an unofficial preliminary investigation, since it is necessary to counterbalance the asymmetry deriving from the different positions of the parties. ${ }^{17}$

Then, the Court of Cassation ${ }^{18}$ clarified that, as regards international protection, the assessment procedure carried out by the judge should firstly consider the subjective credibility of the applicant's version of the life-threatening

15 Civil Cassation, Section VI-1, ordinance 10 April 2015 no. 7333.

16 See Court of Cassation, 16 July 2015, no. 14998 and Court of Cassation, 21 July 2015, no. 15275 .

17 Court of Cassation, no. 25534 of 2016.

18 Court of Cassation, no. 16925 of 2018; no. 28862 of 2018. 
facts. Therefore, if the declarations are judged to be unreliable (on the basis of the indicators of subjective authenticity of art. 3 of Legislative Decree no. 251/2007), an informal in-depth investigation into the situations of persecutions in the countries of origin is not necessary, unless the lack of truthfulness derives exclusively from the impossibility of providing probative evidence.

An example of what just explained is the 22 January 2016 ordinance of the Court of Rome, which granted the refugee status to an Egyptian citizen of Coptic Orthodox religion forced to flee with her family after threats and acts of persecution. In order to support her statements, the applicant presented numerous documents: some aimed at demonstrating her personal condition (e.g. identity documents and baptismal certificates for all her family members), others relating to the socio-political-religious situation of Egypt. However, since the judge has to evaluate the effective protection of the right to religious freedom, changes occurring at institutional level are not enough. In fact, art. 64 of the Egyptian Constitution recognizes religious freedom as an absolute right and allows the Religions of the Book to practice religious rites and build places of worship within the limits set by law. Nevertheless, as confirmed by reports by authoritative international organizations examined by the judge, a progressive and dramatic deterioration in the protection of human rights is taking place in Egypt. Indeed, the ordinance shows that state authorities have not done enough to fight discrimination against religious minorities, especially Shiite Muslims, Bahá'is and Coptic Christians, who, after President Morsi's destitution, were subject to new attacks of sectarian origin and encountered many obstacles in the construction of new places of worship and in the maintenance of the already existing ones. Therefore, the persecutions suffered, the fear of suffering new ones, as well as the information gathered on the country of origin, have led the judge to find concretely proven "the circumstance according to which the applicants, in case of repatriation, would objectively be sent back to persecution", thus recognizing them the refugee status.

On the contrary, the Court of Cassation quashed a decision of the Court of Appeal relating to an asylum-seeker of Christian religion who had stated to have lived in Benin City until the death of his parents, killed by the Muslims of Boko Haram, and to have moved to Abuja in the house of a friend later killed by terrorists. The Court did not specify the reasons why the story was considered to be not credible and contradictory. After the applicant's assertion that violence for religious reasons happened in an area of the country different from the one he was from, the Court did not take into account that he also declared to have tried in vain to escape and find shelter in another area of the country. ${ }^{19}$

19 See Court of Cassation, Section 6-1, no. 12135/2013. 
In March 2015, the Bari Court of Appeal decided the case of a Pakistani Ahmyahite citizen who had faced persecution along with all of his family members: his father was arrested while an intimidation campaign was going on against his two children. After having already suffered persecution, the fear of having to suffer again increases, except that the circumstances of the individual case indicate the opposite (art. 3, par. 4 of Legislative Decree no. 251/2007). A relevant element to ascertain the validity of such fear (as in the case under examination) is the fact that other subjects of the same environment as the applicant's, or other individuals who find themselves in the same situation, have already been victims of persecution in that territorial context. In that case, in the recognition of the status a key role was played by the ascertainment of a widespread intolerance, which had not been fought by the authorities, and which has affected the life of the whole Ahmyahite community in Pakistan.

The Court of Appeal, in opposition to what was decided by the Court of first instance, states that "considering the situation of the country of origin and the significance of what has been discovered about the risks to the lives of the individuals (the story is coherent and credible, as can been proven by the leaflet reporting a threat of death, as well as the promise of an economic reward for those who would find the applicant and his brother - later on, the applicant would tell the same story without any uncertainties), in reform of the decision under appeal, the applicant must be granted the political refugee status, on the basis of the knowledge that, in the event of a return to the country of origin, he would face discriminations or life threats perpetrated by members of other religions". With reference to this matter, it was also observed that "the threat justifying such protection is not necessarily posed by the State, as it may also come from other subjects when state authorities are unable or unwilling to provide adequate protection, as stated in art. 6, par. 2 of Legislative Decree n. 251/2007".

Similar observations are present in the 11 November 2018 ordinance of the Court of Ancona on the appeal against the rejection of the application for international protection submitted by a citizen of Bangladesh who was being persecuted in his country for religious reasons. We can see how in this case, too, the Court considers that "with reference to the evaluation of the truthfulness of the declarations, the Commission finds lack of credibility to the story assumption that we cannot support. In fact, the legislative parameters to decide on the reliability of the declarations made by the asylum seeker are established by art. 3, par. 5 of Legislative Decree no. 251/2007. Moreover, the Commission observes a correspondence between what was highlighted by the applicant and the information gathered from the sources (...). In truth, the 
applicant's story appeared to be credible because it was fully detailed, as well as confirmed by the information collected (...)".

Here is another case concerning a Sunni Muslim coming from Pakistan, who was the subject of persecution by members of his own religious group because of the good relations he used to have with some Shiites. The hostility of the Sunnis towards him precluded him from the possibility of obtaining protection from state authorities and left him without any shelter: shut out by the majority, not belonging to any minority, and neglected by the State. In the absence of further evidence besides his declarations, the Court of Appeal of Palermo (sentence no. 281 of 15 February 2016), in accordance with art. 3 of Legislative Decree no. 251/2007, considered the applicant's effort to substantiate his claim to be decisive. However, as for similar cases, the ruling clarifies that it is not possible to make "any decision that may result in the return to the country of origin of a person who could suffer serious harm there". Besides the fact that the person requesting protection does not have to belong to a persecuted minority, since persecution for religious reasons may arise from many different events, the Sicilian judge stressed the central role of the credibility of the asylum seeker, and drew attention to the subjective opinion of the judge.

Back in 2010, the Court of Cassation, with sentence no. 26056, ruled on similar cases, introducing two criteria. The first case concerned a Nigerian citizen of Catholic faith. His views were considered as contradictory and vague by the Court of Appeal of Turin, which stated that, in this type of disputes, the burden of proof mainly falls on the applicant and any lack of arguments could not be filled by the powers of instructions of the judicial organ. On the contrary, the Court of Cassation reiterated the obligation of the judges to cooperate actively in the investigation phase, and stated that granting of refugee status cannot be based exclusively on the credibility of the applicant and the duty of the latter to prove the oppression suffered. Furthermore, the Court adds, the truthfulness of the persecution can be ascertained thanks to external and objective information concerning the country of origin, and it is the connection of these conditions to the present case that will help verify the asylum seeker's credibility.

Another interesting decision of the Court of Cassation ${ }^{20}$ confirms the ruling of the Court of Appeal of Naples rejecting, for lack of requirements, the request for international protection due to religious persecution perpetrated by the parents of the applicant. While reaffirming that, hypothetically, even

20 Civil Cassation, Section vi, no. 21612/2018, available at: www.dirittoimmigrazionecittadinanza.it/archivio-fascicoli/fascicolo-2018-n-3/54-rassegne-di-giurisprudenza-n-3-2018/ rassegne-di-giurisprudenza-italiana-n-3-2018/88-asilo-e-protezione-internazionale. 
parents can be agents of persecution for religious reasons, in this case the applicant's statements were not considered as credible: he, in fact, had reported that he had always lived with his parents and had attended Christian schools, thus leading the judge to believe that it was unlikely that the applicant's father might not approve of the faith that his son had matured in the Christian school the parents themselves had enrolled him at.

There are also cases of religious persecution among the different currents of thought within the Islamic religion. The 15 November 2017 decree issued by the Court of Brescia ${ }^{21}$ granted the refugee status to a Pakistani citizen who was the Imam of a mosque and who used to teach the Koran to children. The Court judged the applicant's story to be credible by linking the religious persecution he was facing to his role as a Koran teacher inside a mosque (he belonged to the Barelvi religious group) and to having refused to stop his religious teaching. In the decree, the Court, while exercising its duty of cooperation, allowed the appellant to clarify some aspects that seemed to be unclear during the hearing in the previous administrative phase.

The Court of Rome has recognized a Nigerian citizen the refugee status because of the persecutions of Christians in his country. Thanks to a newspaper article presented to the Court and reporting his story of persecution (he had received threats by a terrorist organization because of his Christian faith), the plaintiff managed to prove the truthfulness of his words. As the Court reaffirms, the fact that the threats are not posed by state authorities does not prevent the recognition of the protection. Indeed: “(...) even if the danger the plaintiff is exposed to cannot be linked to any activity of the State, the thirdcountry national can still consider well-founded the fear of suffering serious damage in case of return to the country of origin, given the context of religious conflicts in many areas of the Country". 22

What is even more challenging, in relation to religion, is the recognition of the subsidiary protection to the foreigner or to the stateless person who flees from a specific country for the well-founded fear of suffering serious damage resulting from death penalty, torture, inhuman or degrading treatment or generalized violence to civilians in situations of internal or international conflict.

The Cassation has granted the status of subsidiary protection (and not the refugee status) to a third-country national (in this case, escaped from Pakistan not to join the Taliban militias) because the violent pressure he was put under was not dictated by the willingness to impose a religious option, but by the rifugio-2/217-5-trib-brescia-15-11-2017-rifugio/file.

22 Court of Rome, I Civil section, sentence no. 20908 of 21 October 2013. 
need to enlarge an armed organization. Besides, his refusal was not due to religious reasons. ${ }^{23}$

It is also worthwhile mentioning both the ruling concerning the recognition of humanitarian protection to a Benin citizen, given the significant danger of enforcement of the Shari'a against the applicant in his country of origin, and the ruling that granted subsidiary protection to a Pakistani citizen because of the risk of possible persecution linked to his religious faith.

The issues relating to the persecutions of new religions and sects and the persecution in the case of conversion to another religion are of particular importance. The persecution of sects or "new religions" is observed especially in countries where the law provides for oppressive conditions to legitimize the action of religious confessions. The term "sect" is often one of the tools used in some countries to discriminate or persecute certain new, non-traditional religious groups, which are not submissive to political power. However, it is not allowed to deny the refugee status only because the creed that is subjected to persecution is considered as a sect or because sects are not religions, but pseudo-religions. $^{24}$

An example of an upheld appeal is the sentence of the Court of Trieste of 2 January 2018. It concerned a Chinese woman who reported having left her country of origin because, due to her religious faith, she was being sought by the authorities - who were persecuting the members of the so-called House Churches by arresting and torturing its followers and its promoters. In particular, the applicant reported being intimidated by the authorities, which led her to flee her country. The Court of Trieste had criticized the territorial commission's rejection of the request because "without consulting specific sources, it estimated that there were no reasonable grounds to believe that if the applicant had returned to China, she would have run the risk of suffering serious harm, pursuant to the provisions of art. 14 of Legislative Decree 251/2007" even if in that case "the intrinsic reliability of the applicant's story (...) is linked to the extrinsic one. The circumstances described are in line with the information acquired; the religiosity of the applicant seems to be deeply convinced: in such a homogeneous context, even the more uncertain circumstances relating to her escape from her country remain credible".

As recalled by the Court of Bari, civil Section II, through the ordinance of 7 April 2016, the darwishi gonabadi religious current (of the ascetic and mystic type of Sufi Islam diffused in Iran and Turkey) according to reliable international

23 See Court of Cassation, Section 6-1, no. 12075/2014, Rv. 631321-01.

24 General Comment no. 22 of the International Covenant on Civil and Political Rights, 1993, no. 2. 
sources has been persecuted for years by the Iranian government. For this reason, it can be stated that its followers have been persecuted by state forces because of their religious affiliation.

Furthermore, it is useful to mention the 22 May 2018 ordinance of the Court of Perugia. In evaluating whether a person has the right to obtain international protection, judges cannot make their decision exclusively on the basis of the personal credibility of the applicant and of the fulfillment of the burden of proof relating to the existence of the fumus persecutionis against him/her in the country of origin. The judge, in fact, must verify that there actually is a persecution of opinions, habits, and practices by basing on external and objective information relating to the situation of the country of origin. However, in order to prove the fumus persecutionis, the applicant can also use elements of personal evaluation, including the credibility of the declarations of the interested party. The judge, therefore, has a duty to carry out an extensive investigation, obtain all the documentation (even if unofficial) and generally assess the actual situation of the country of origin. The specific case was an appeal against the refusal of international and humanitarian protection of a Chinese woman belonging to the "Church of God Almighty" who was forced to flee her country, since the cult she belonged to was being persecuted (Soryte, 2018).

In this case, the Court states again that "the reasons given in this regard by the commission are not convincing, as (...) the applicant's statements appear to be intrinsically coherent and credible (...) and correspond to the actual characteristics of the cult"; “(...) it must also be noted that the applicant has tried to provide all the elements in her possession in order to prove that she belonged to the cult (...) therefore, for the purpose of recognizing the refugee status to the applicant, the Court must acknowledge that she has a wellfounded fear of being persecuted for religious reasons, both from a subjective and an objective point of view, since the applicant's statements in this regard appear to be in line with the latest news on religious freedom in China (...) we must consider that the article 300 of the Chinese Penal Code, which also punishes those who participate in superstitious sects, is interpreted by the jurisprudence in the sense of punishing even those who are active in a superstitious sect; thus, it is sufficient to be identified as a member of a forbidden cult to be arrested and sentenced to prison for even more than seven years, in case of serious circumstances".

The persecution in case of conversion has been as well recognized in many cases, both in administrative and judicial cases. In the administrative practice, a decision of the territorial commission of Rome is fundamental, as it recognized the refugee status to all the members of a Christian Egyptian family, in which the mother was sexually harassed and the father was convicted for 
apostasy, was the subject of discrimination in the workplace, and even received death threats and was abused by the police in order to force him and his children to convert (Benvenuti, 2011). The ordinance of the Court of Bari, II civil section, of 15 March $2017^{25}$ recognized the status of refugee to an Iranian man, whose conversion to the Catholic religion gave rise to religious persecution and to a warrant for his arrest. The Court recalled that his conversion was known to the state authorities, because of his father's (a Hezbollah) complaint, as well as because of the discovery of a box containing copies of the Bible (and kept by the applicant, as requested by a friend, inside his computer shop) and after a search carried out by the police in the house of the applicant's family. The judge examined the condition of Christians in Iran also through the consultation of an essay on being Christians in Iran today, published in an Italian magazine, through the reading of passages from the Koran (where the crime of apostasy is unfounded) and in the light of the number of people hanging themselves after President Rouhani took office.

Lastly, today in Italy the effective protection against any form of religious persecution no longer appears to be guaranteed when it concerns either a citizen of a State included in the list of safe countries of origin or a stateless person who legally resides there. In fact, by making use of the faculty provided by the EU directive, art. 2-bis of Legislative Decree 25/2008 (added in 2018) gives the Minister of Foreign Affairs and Cooperation, in agreement with the Ministers of Interior and of Justice, the faculty to approve a list of safe countries of origin. As shown by the information gathered by national, European, and international bodies, in these States the risk of suffering persecution, torture, inhuman or degrading treatment or even general violence during conflicts can be ruled out thanks to their democratic system, their current laws and the effective application of said laws; besides, the rights and the jurisdictional guarantees provided for in the International Covenant on Civil and Political Rights, in the European Convention for Human Rights, in the International Convention against Torture and in the Convention on the Status of Refugees are effectively ensured.

The Decree of the Minister of Foreign Affairs of 4 October 2019 designates as safe countries of origin Algeria, Morocco, Tunisia, Albania, Bosnia, Cape Verde, Ghana, Kosovo, Montenegro, Northern Macedonia, Senegal, Ukraine, and Serbia. However, such Decree appears to be illegitimate since these countries, except for Cape Verde, do not have the required requisites for this qualification. In fact, some of these States have a legal order based on a state religion and the

25 Available at: https://www.dirittoimmigrazionecittadinanza.it/allegati/fascicolo-n-2-2017/ rifugio/90-4-ordinanza-tribunale-di-bari-iran-conversione/file. 
people who do not belong to said religion, or stop practicing it, cannot fully enjoy religious freedom and can suffer legal discrimination, criminal sanctions or other forms of persecution for religious reasons (Morocco, Algeria, and Tunisia). Besides, in some of those States, conflict situations are underway for religious reasons and certain sexual orientations are considered as a criminal offense.

This Decree will not only speed up the procedures for examining the applications submitted by the citizens of the States defined as safe and by the stateless persons residing there. Since the applicants coming from those countries have the burden of bringing elements showing that, in their personal situation, their country is not safe, the Decree will also deter the submission of applications and the possible subsequent jurisdictional appeals. Besides, it will cause a decrease in the positive results of the applications. ${ }^{26}$

26 In fact, the designation of the safe country of origin produces the following effects on the applications for international protection presented by citizens of the designated State or by stateless persons staying there: 1 ) The authority examining the application is exempt from the obligation to collect the information on the country of origin ex officio, but the applicants have the burden of invoking serious reasons showing that, in their specific situations, their country is not safe (art. 2-bis, par. 5 of Legislative Decree 25/2008); 2) Denying the applications adopted by the Territorial Commission for the recognition of international protection due to manifest groundlessness is justified only when the applicants have not demonstrated that there are serious reasons to believe that, in relation to their specific situations, the designated safe countries of origin are in fact unsafe, thus making them run the risk of persecution or serious damage (art. 9, par. 2-bis of Legislative Decree 25/2008); 3) Upon presentation of the applications for international protection, the police office informs the applicants that the application can be rejected as manifestly unfounded simply because they have not demonstrated the existence of serious reasons for considering the designated safe countries of origin to be unsafe in relation to their specific situations, thus making them run the risk of persecution or serious damage (art. 10, par.1 of Legislative Decree 25/2008); 4) The request for international protection is examined by the Territorial Commission as a priority (art. 28, par. 1, letter c-ter of Legislative Decree 25/2008) and with an accelerated procedure: as soon as the request is received, the police station immediately proceeds to the transmission of the necessary documentation to the Territorial Commission, which makes a decision within five days (the deadline can be extended to ten days or more if the application is deemed manifestly unfounded and needs a more in-depth examination). If the application is presented in the border or transit area, the examination can take place directly at the border or in the transit area (art. 29, par. 1.1-bis, 1- ter and 1-quater, 2 and 3 of Legislative Decree 25/2008); many of the citizens of the countries included in the list of safe countries of origin arrive in Italy precisely in the border areas identified by the Ministry of the Interior Decree of 5 August 2019, that is southern Sardinia and southern Sicily (especially the citizens of Tunisia, Algeria and Morocco, who make up $40 \%$ of the average number of irregular entries from the sea and the Bosnian, Kosovar and Montenegrin citizens who enter the border areas of Apulia in southern Italy or of Friuli Venezia Giulia in northern Italy); 5) The rejection of the 


\section{Persecution for Multiple Reasons: Religion and Sex, Religion and Sexual Orientation}

Discrimination and persecution can also be based on reasons other than religion.

For example, the persecution against those who fight to change their State from a confessional one to a secular one, in which people can freely express atheistic ideas, is a persecution both for religious and political reasons.

There are also persecutions and discrimination against women, i.e. for reasons connected with belonging to the female gender, but which are also motivated by political and religious reasons. In this regard, it must be highlighted that persecutions could also happen if the persecutor supposes that the person belongs to a particular religion. In the administrative practice, for instance, there was a case of an Eritrean female citizen who suffered imprisonment and mistreatment because of her supposed membership to the Pentecostal Church. She was granted the refugee status after having verified her credibility on the basis of her very declarations.

application for the international protection by the Territorial Commission due to manifest groundlessness involves, at the end of the term for the appeal (reduced to 15 days by art. 35, par. 2 of Legislative Decree 25/2008), the obligation for the applicant to leave the national territory, unless he/she has been issued a residence permit for another reason, and the adoption in his/her regard of an administrative expulsion order by the prefect, which is executed by the quaestor who accompanies the applicant to the frontier; if this is not executable, the quaestor can also issue a detention order to keep the applicant in a center for repatriation (art. 32, par. 4 of Legislative Decree 25/2008); 6) The enforceability of the rejection due to manifest groundlessness cannot be suspended by the mere presentation of the judicial appeal to the court, as it can be suspended only for serious reasons and after having issued a decree motivated by the court judge, pronounced within five days since the submission of the request for suspension, without the prior call of the counterpart and, if necessary, after having gathered more general information. The decree that either grants or denies the suspension of the disputed provision is notified to the parties. Within five days since the notification, the parties can file defensive notes. Within five days after the expiry of this deadline, replies may be filed and the judge, with a new decree to be issued within the next five days, can confirm, amend or revoke the measures already issued. In any case, such decrees are not subject to appeal, and only once the request for suspension has been accepted, the applicant is issued a residence permit due to the asylum request (art. 35-bis, par. 4 of Legislative Decree 25/2008); 7) When the appellant is admitted to patronage at the State's expense and the appeal concerns a decision, adopted by the Territorial Commission, that is manifestly unfounded, the judge that rejects the appeal indicates in the decree for the payment of the expenses by the State the reasons why the claims of the plaintiff cannot be considered as manifestly unfounded (in the absence of those reasons, the costs of the proceedings are charched to the applicant and not to the State). 
In this regard, another case can be mentioned. By keeping in mind that in such cases judges must exercise their broad powers of instructions and collect all the information useful to reconstruct the narrative context, the Court of Cassation (ordinance no. 24064 of 2013) approved the appeal of a Cameroonian woman, accused of witchcraft in her country. According to the Court, any anthropological analysis would have made it possible to ascertain that the accusations of witchcraft constitute a sociocultural-religious phenomenon that is widespread in the community of origin of the applicant, just as convictions for common crimes that cover up convictions for witchcraft. From such analysis, it could easily have emerged that the applicant had been convicted on the basis of persecution for, in the broad sense, religious reasons (Benvenuti, 2011).

On the contrary, when the condemnations for witchcraft are inflicted by local courts against women to punish serious common crimes, such as murders, these acts are meant to prevent all forms of self-determination and, even if they are not aimed at harming women's religious freedom (therefore not legitimizing the recognition of the refugee status) they can cause the compression of fundamental rights and could thus legitimize the recognition of minor international protection measures (Acierno, 2019), i.e. the status of subsidiary protection or of special protection.

More generally, since any act specifically directed against a sexual gender is considered as persecution (art. 7, par. 2 of Legislative Decree no. 251/2007), in a case concerning a Nigerian citizen, the Cassation has found that a woman, as such, can be persecuted for belonging to a social group and, at the same time, for religious reasons - if she rebels against a code of conduct, against duties and responsibilities, against men (Madera, 2018).

Genital mutilation, as it is performed against the female gender, can also be based on religious motives. In fact, the jurisprudence has observed that since their genesis lies in deep cultural traditions or religious beliefs, women's refusal to subject themselves or their daughters to such practices exposes them to the actual risk of being considered, in their country, as political opponents or as subjects that reject religious models and social values, and are therefore persecuted for this reason. So, they must be granted the status of refugee to stop gender violence as well as the discriminatory treatment that would ensue in case of refusal to submit to the violence (Cattelan, 2013).

More generally, violence against women can also occur because of religious reasons. In this sense, Courts grant subsidiary protection when a female is forced to an unwanted marriage and authorities do not oppose it, thus leaving any decision to the patriarchal family or a religious structure.

Thus, the Cassation includes in the concept of domestic violence (pursuant to art. 3 of the Istanbul Convention of 11 May 2011 on preventing and combating 
violence against women and domestic violence, enforced in Italy by the law of 27 June 2013, no. 77) a case of restriction on enjoyment of fundamental human rights imposed to a woman, of Christian religion, because of her refusal to abide by the custom of her own village - according to which, after becoming a widow, she had to get married to her brother-in-law. The Cassation decided so even if the tribal authorities, to which the woman had asked for help against her brother-in-law, had allowed her not to marry him - since that was on condition that she left the village, leaving her children and her belongings behind. According to the Court, these acts, pursuant to art. 5, letter c of Legislative Decree no. 251/2007, meet the requirements of persecution pursuant to art. 7 of Legislative Decree no. 251/2007, even if implemented by non-state authorities, if -as in this case- state authorities do not fight them or do not provide any protection, as they are the result of local customary rules. The ruling also refers, at the soft law level, to the UNHCR guidelines of 7 May 2002 on genderbased persecution, whose point no. 25 specifies that persecution occurs even when a woman is prevented from enjoying her rights because of the refusal to conform her behavior in accordance with traditional provisions relating to her gender. In another case concerning a Moroccan female citizen, victim of abuse and violence (which would go on even after the divorce) perpetrated by her husband, who had been punished by the Moroccan justice with a bland criminal sanction, the Cassation ${ }^{27}$ (always by referring to articles 3 and 60 of the Istanbul Convention), albeit to the effects of subsidiary protection, links the acts of domestic violence to the issue of inhuman and degrading treatment, asking the judge to verify concretely whether, despite the threat of serious damage by a "non-state subject", pursuant to art. 5, lett. c of Legislative Decree no. 251/2007, the country of origin of the applicant is able to offer adequate protection.

There are also persecutions and discrimination against people because of their sexual orientation, and at the same time because of religious reasons. Persecutions for sexual orientation are connected to the fact of belonging to a specific social category, and they can also be considered as religious persecutions when there are religious motivations, too. The persecutor can link religion to homosexuality by using religion to legitimize the persecution and the discrimination or to define homosexuality as a sin, as an abomination or as a form of apostasy (Ferrari, 2018). There are frequent cases of persecution for sexual orientation in the Islamic world, as the social context is marked by values that are hostile to homosexuality, which can be punished with death penalty, with imprisonment, or with other discriminatory and persecutory acts. 
The Court of Catanzaro (ordinance of 2 July 2015) recognized the persecution of a Bengali citizen who was having a homosexual relationship and, for that reason, was denounced to the mullah, who issued a fatwa against him. He managed to escape, but then he was falsely accused of having caused a fire in a shop - which killed an entire family and for which he was sentenced to death. The same Court (ordinance of 7 December 2015) also recognized the persecution of a Ghanaian citizen who was having a relationship with his cousin and who later fled for fear of being killed by his father - an imam who had never accepted his homosexuality (Abu Salem, Fiorita, 2016).

The Religious Aspects in the Examination of Asylum Applications and in the Reception System

The religious affiliation of asylum seekers, which is essential for the recognition of one of the forms of protection provided by the legal system, however, appears to be scarcely relevant during the procedures for examining and deciding on applications, although every territorial commission for the recognition of the international protection has also been composed, since July 2018, of four experts on human rights, including religious rights, and gathers information on the situation of the countries of origin (also with reference to the religious rights) from specific databases managed by the National Commission for the right to asylum or by the European Asylum Support Office (EASO).

Every Commission, whenever necessary in order to examine the application, may consult experts on particular topics, such as health, culture, religion, gender and minors (art. 8, par. 3-bis of Legislative Decree 25/2008). Besides, during the personal interview with the commission, the applicant can request not to use the video recording (also for religious reasons) and the decision lies with the Commission, and not with the individual commissioner in charge of conducting the personal interview. The decision cannot be contested (art. 14 of Legislative Decree 25/2008).

Religion is hardly taken into consideration in the effective management of the reception system for asylum seekers and for people granted asylum. In centers where foreign nationals seeking asylum are detained (repatriation detention centers or first aid or reception centers or government reception centers) or in the preliminary reception centers where asylum seekers are initially hosted to be identified and to be allowed to submit the asylum application, applicants are granted the right to speak to ministers of worship (art. 7, par. 2, and 10, par. 3 of Legislative Decree no. 142/2015). In the detention centers for repatriation, the freedom to speak to other people within the center must be 
guaranteed, as it must be ensured the freedom to talk to visitors, such the ministers of worship, as well as the freedom of worship, within the limits set by the Constitution (art. 21, par. 1 and 2 of Presidential Decree 394/1999). It is not clear if this limit refers to the limit set in art. 19 of the Constitution (which concerns rites against public morality) or if it refers to some other limits (Consorti, 2011). Even inside the governmental centers for asylum seekers, specific spaces must be designated for various activities, including activities of worship (art. 9, par. 3 of Presidential Decree of 12 January 2015, no. 21). Finally, every project to create a reception service for asylum seekers, undertaken by Italian local authorities within the framework of the SPRAR (Protection System for Asylum Seekers and Refugees), for which the local authority asks for funding from the National Fund for Asylum Policies and Services, has to make sure that the people hosted are guaranteed food and the fulfillment of other needs by respecting their cultural and religious traditions (art. 31, par. 2 of the guidelines for the functioning of the protection system for asylum seekers and refugees, attached to the Ministerial Decree of 10 August 2016).

Even if the Legislative Decree no. 113/2018 has reformed the entire reception system, in art. 1, par. 9 of the new tender specifications scheme attached to the Ministerial Decree of December 2018 for the management of preliminary reception facilities, of extraordinary reception centers for asylum seekers activated by the Prefects, and of repatriation detention centers where asylum seekers can be held, it is reiterated that the organization of reception services is based on the full respect of the fundamental rights of the individuals, also in consideration of their religious faith. However, there are no specific details in order to explain the implementation of this principle in the various typologies of centers: first aid and reception centers, governmental preliminary reception centers, hotspots, temporary reception centers for repatriation, and extraordinary reception centers (the Italian CAS, which can be both collective centers and housing units).

Furthermore, the aforementioned norms fail to indicate which ministers of worship are actually allowed in the various centers - which partially limits the effectiveness of the norm, for whose implementation it will be necessary to resort to the unilateral provisions used for other forms of spiritual assistance, even if -so far-no norm inside the various agreements with the religious confessions has yet dealt with such topic (Carnì, 2015).

This gap remains intact for all types of reception centers for asylum seekers, who can freely satisfy any religious need outside, while it is apparently bridged for the repatriation centers, in which foreigners are detained and therefore their personal freedom is restricted, as they are supervised by the police and cannot leave without proper permission. The centers for repatriation have the 
same rules as the penitentiary institutes as to the indication of the subjects authorized to visit the centers, with particular reference, for example, to the ministers of Catholic worship and other cults, who can visit after being authorized by the director of the center.

The right to profess one's own religion is fundamental to respect the dignity of each individual and, in order to satisfy this need, the legal system has tried to grant religious assistance to all those whose personal freedom is restricted. As a result, the principle of secularity of the State, meant as the protection of each person's religious freedom, requires the State to guarantee the religious freedom of those who are deprived of the possibility of exercising it autonomously, so that the ministers of worship must be allowed into temporary detention centers, specific spaces to pray must be ensured, and other religiously motivated requests concerning food, clothing and the display of symbols must be accepted (Fiorita, 2007). In this regard, the regulation defining the "Criteria for the organization and management of the centers for identification and expulsion", issued by the Ministerial Decree of 20 October 2014, provides that in each CIE (now renamed as Temporary Reception Centres for Repatriation) recreational, social and religious activities must be organized in specific spaces and, to this end, the manager has to prepare a weekly calendar of the planned activities to be shared with all the foreigners living there.

However, the first inspections carried out in February-March 2018 by the national Guarantor of the rights of the detained persons and of those deprived of personal liberty in all the centers for repatriation have shown that, in every center, the rules mentioned above regarding the exercise of each person's religious freedom and the access of the ministers of worship appear to be substantially unobserved. The report issued by the Guarantor ${ }^{28}$ is critical: all the centers visited had no space to be utilized as a place of worship (for example, the daily prayers of people of Islamic religion would take place in the corridors, while no space at all was guaranteed to the Christians) and the possibility of religious practice was severely limited because no minister of religion could visit. Therefore, the national Guarantor recommends that a program of activities should be outlined in full compliance with the CIE's single Regulation and, due to a serious lack of said recreational, social and religious activities, it invites the Ministry of the Interior to carry out a strict monitoring of the managing bodies' obligations derived by the contract regulating the supply of

28 Italian Guarantor of the rights of the detained persons and of those deprived of personal liberty, Rapporto sulle visite tematiche effettuate nei centri di permanenza per il rimpatrio $(C P R)$ in Italia (February-March 2018), available at: http://www.garantenazionaleprivatiliberta.it/gnpl/resources/cms/documents/c3oefc290216094f855c99bfb8644ce5.pdf. 
the aforementioned activities. ${ }^{29}$ However, it seems that only the Prefecture of Bari was willing to push the managing body to use specific spaces in the center of Bari as actual places of worship. ${ }^{30}$

Consequently, it seems that, in order to put security first, the needs connected to freedom and assistance, including the religious and the spiritual ones, are overshadowed: these needs are protected at the highest constitutional level, but nevertheless seem to be relegated to elements of form - which confirms that, in practice, guaranteeing public order turns out to be more important than protecting the inviolable rights (Consorti, 2011).

This notion is confirmed if two particular aspects are taken into account.

On the one hand, it is clear that there is an underestimation of the religious dimension in the management of the reception centers for unaccompanied foreign minors. In fact, the Guidelines to apply for financial aid for the National Fund for Asylum Policies and Services for the reception of unaccompanied foreign minors first demand that each center respect the cultural and religious traditions of the guests. Besides, in order to meet the cultural, linguistic and religious needs of minors, they demand the use of linguistic and cultural mediators in every service provided, so that they can bridge the gap between the two cultures, i.e. the one of the welcoming context and the one brought by the minors (Ministerial Decree of 27 April 2015, Annexes 2.1 and 2.5). However, article 18 of Legislative Decree no. 142/2015 does not specify if the exercise of religious freedom has to fall in the category represented by "the living conditions that must be guaranteed to each minor, with regard to the child's protection, welfare and development, including the social one", or that the child's previous religious habits must also be taken into consideration in the evaluation of the minor's best interest; it does not even specify that among the various needs of minors hosted in the reception centers there are also the religious ones. The needs connected to the effective exercise of religious freedom do not even seem to be precisely indicated in the list of fundamental rights of the minor. Moreover, no detail regarding the religious aspects of the child's life is expressly stated in the Ministerial Decree of 1 September 2016, which sets up the governmental preliminary reception centers destined to unaccompanied foreign minors. All this can cause unpredictable effects on how these minors (under

29 Italian Guarantor of the rights of the detained persons and of those deprived of personal liberty, Norme e normalità. Standard per la privazione della libertà delle persone migranti. Raccolta delle Raccomandazioni 2016-2018, p. 29, available at: http://www.garantenazionaleprivatiliberta.it/gnpl/resources/cms/documents/ef9c34b393cdocb696o fd724d59ofo62.pdf.

3o Italian Guarantor of the rights of the detained persons and of those deprived of personal liberty, Report to the Italian Parliament 2019, p. 195, available at: http://www.garantenazionale privatiliberta.it/gnpl/resources/cms/documents/ooo59ffe97od21856c9d52871fb31fe7.pdf. 
the supervision of guardians and managers of the reception centers) relate to the different places of worship, the ministers of worship and the religious education at school and out of school. The constitutionally guaranteed religious freedom requires that, in the "best interests of the child", religious education must be taken into primary consideration, as well as the minor's linguistic needs and the minor's requests for changing or deepening the religious experience.

On the other hand, an underestimation of the religious aspects in the reception of asylum seekers is evident, both in everyone's life and in the overall management of each center. In fact, it must be remembered that all reception centers for asylum seekers must adopt appropriate measures to prevent all forms of violence, including gender-based violence, and to guarantee the safety and the protection of both the applicants and the staff working at the centers (art. 10 of Legislative Decree no. 142/2015). Besides, the reception measures take into account the specific situation of vulnerable persons, such as minors, unaccompanied minors, disabled persons, the elderly, pregnant women, single parents with minor children, victims of trafficking in human beings, persons suffering from serious illnesses or mental disorders, persons subjected to torture, rape or other serious forms of psychological, physical or sexual violence or violence linked to sexual orientation or gender identity, and victims of genital mutilation. In fact, people who have suffered torture, rape or other serious acts of violence are guaranteed appropriate medical and psychological assistance or treatment (art. 17, par. 1 and 8 of Legislative Decree no. 142/2015).

At the same time, seriously violent behaviors perpetrated by the hosted people legitimize the revocation of the reception measures (art. 23 of Legislative Decree no. 142/2015). These rules explain why the religious belonging of the guests of the reception centers for asylum seekers always seems to be taken into consideration, in order to prevent any danger to the safety of both the guests and the staff deriving from possible interreligious tensions. These dangers (which are concrete, as they can also be observed in other EU countries welcoming asylum seekers) can affect the lives of the asylum seekers who have fled the persecutions or the religious discrimination occurring in their country of origin. Of course, it could turn out to be potentially dangerous for them to find themselves living in a reception center alongside other foreign guests belonging to a hostile religious confession. The possibility of episodes of intolerance and violence, in these circumstances, could increase and endanger the safety of all the guests at the reception centers.

Moreover, in the projects aimed to build SPRAR centers that have been approved so far, there has been no analysis of the religious aspect, except for the administration of food (in order to respect the dictates required by the different 
religions) and for the designation of mediators to partially fulfil the need for a cultural and religious integration.

Nevertheless, some calls for tenders for the management of extraordinary reception centers for asylum seekers require that guests be allocated by taking into account their religious affiliation in order to prevent any tension between guests belonging to different religious denominations. For example, in the attachment to the Public notice of call for tenders of the Syracuse Prefecture of 14 January 2016, it is indicated that "the Prefecture maintain the power to manage the reception in the structures of the chosen subjects according to criteria meeting the needs of protection of the dignity, the safety and the physical integrity of the applicants, especially if vulnerable, as well as any need to safeguard public safety. For instance, the same structure will not include at the same time the following: $a$ ) guests of different ethnicities or of different religions that are in conflict or in a strong state of tension". This means that, instead of providing guidelines for the management of conflicts that could hypothetically arise within the structure, the Prefecture makes a prognostic judgment, with the aim of preventing possible critical issues.

The failure in preventing difficulties concerning the interreligious coexistence in the reception facilities for asylum seekers appears to be a serious contradiction with reference both to the effectiveness of the protection of religious freedom, and to the safeguard of right of asylum - as these people flee from countries where they cannot exercise their freedom. As a result, the formal recognition of the foreigner's religious freedom is ineffective if it is not ensured even in the person's daily life.

\section{The Constitutional Aspects of the Religious Dimension of Foreign Nationals in Italy}

Since religious freedom belongs to anyone who lives in Italy independently of their citizenship, it is very important to examine the discipline of the religious dimension of everyone's life, which can also be applied to the foreigners who have been forced to migrate to Italy.

In fact, the religious freedom guaranteed by the Constitution is associated with an equal social dignity and with the equality of each person before the law, without any discrimination based on religion (art. 3 of the Constitution). This has two meanings:

1) Primacy of the laws in force in the Italian Republic, which everyone must observe, as prescribed by art. 54 of the Constitution, without considering oneself as exempt from the need to observe the norms of one's own 
religion. Any conflicts with other religions can be prevented by the rules adopted pursuant to articles 7 and 8 of the Constitution, which regulate the relations between the State and each religious denomination in a specific and differentiated way. This makes it possible to temper the observance of state norms to the religious norms;

2) Public authorities are prohibited from provide for and implement differential treatment on the basis of religion, unless it is expressly provided for in the Lateran Pacts with the Catholic Church or in the agreements stipulated with other religious denominations (see below).

Therefore, in Italy, any norm contrasting with this fundamental principle of non-religious discrimination is not applicable. Thus, as a result of the prohibition provided by art. 16 of law 31 May 1995, no. 218, norms of foreign legal systems cannot be applied if they cause discrimination based on a particular religious affiliation or a non-religious affiliation - this is the case, for example, of some laws in force in States whose legal order is based on the Islamic Sharia.

The prohibition of religious discrimination does not mean that every religious confession and that every believer has the right to obtain the same treatments guaranteed to other religions, but it means that every person has the right not to suffer any discrimination based on religious affiliation, on the change of religion, or on atheism. Moreover, art. 3 of the Constitution does not prevent the legislator from introducing reasonably different treatments to regulate "not substantially identical" situations. Besides, in compliance with the "supreme principles of the constitutional order", some norms can be waived by other particular norms which have constitutional coverage - for example, those established by the Concordat with the Catholic Church (referred to in art. 7 of the Constitution) and those found in the agreements with nonCatholic confessions (which are mentioned in art. 8 of the Constitution).

In art. 3 of the Constitution, the prohibition of discrimination is connected to the principle of formal equality and is accompanied by positive obligations for the public authorities, which have to remove the obstacles which constrain equality and freedom. Consequently, the Italian legal system provides for rules that prevent and contrast discriminatory practices implemented both in the relations with public authorities and in the relations between people.

Firstly, incitement to hatred or discrimination for religious reasons are crimes, also because of the international obligations in force in Italy following the ratification of the International Convention on the Elimination of all Forms of Racial Discrimination, adopted by the UN General Assembly on 25 December 1966, which prescribes as punishable under criminal law the dissemination of ideas based on racial hatred, the incitement to commit violence for racial reasons and the participation in associations whose purpose is the 
incitement to discrimination or violence on racial grounds. By implementing these international standards, Decree Law 26 April 1993, no. 122, converted, with modifications, by law 25 June 1993, no. 205, introduced criminal norms punishing propaganda and instigation to commit crimes on grounds of racial, ethnic and religious discrimination. Said norms ended up in 2018 into art. 604bis of the Italian Penal Code. Furthermore, any organization, association, movement or group having as its purpose the incitement to discrimination or to violence for racial, ethnic, national or religious reasons is prohibited.

Secondly, many laws provide for measures to prevent and combat discrimination, including any discrimination for religious reasons carried out in the relations between private individuals. In particular, the Consolidated act of provisions concerning immigration (Legislative Decree of 25 July 1998, no. 286) defines the behaviors that constitute discrimination, also for religious reasons. Article 43 defines as discriminatory "any behavior which, directly or indirectly, entails a distinction, exclusion, restriction or preference based on race, color, national or ethnic ancestry, religious beliefs and practices, and that has the purpose or the effect to destroy or compromise the recognition, the benefit or the exercise, in conditions of equality, of human rights and fundamental freedoms in political, economic, social and cultural fields and in any other sector of public life". Article 43 also provides that, in any case, an act of discrimination is carried out by "anyone who illegitimately imposes more disadvantageous conditions or refuses to provide access to employment, housing, education, training and social services and social assistance to the foreigner legally residing in Italy only because of the status of foreigner or because belonging to a specific race, religion, ethnicity or nationality". Article 44 gives those who consider themselves as victims of discrimination perpetrated by a private individual or by a public administration for religious or ethnic reasons, the right to appeal to the judge to stop the prejudicial behavior.

Finally, the same Legislative Decree, with the aim to prevent and combat discrimination, provides that the Italian Regions, in collaboration with the Provinces and each Municipality, and with the associations of immigrants and social volunteers, set up information and legal assistance centers for foreigners who are the victims of discrimination on racial, ethnic, national or religious grounds. In implementing the law, the national fund for migration policies also finances annual and multi-year programs prepared by the Regions for carrying out activities aimed at preventing and removing all forms of discrimination.

Nevertheless, the national Office for the promotion of equal treatment and the removal of discrimination based on race or ethnic origin (UNAR), in its 2015 report observed an increase in the cases of discrimination on grounds of religion. In the following report, it is noted that the reports of discrimination 
based on "religion or personal opinions" have increased compared to 2015 and that the subtype that mainly originated discriminatory behavior is Islamophobia $(5.3 \%)$, which consists of "an exaggerated fear, hatred and hostility towards Islam and Muslims, as well as of negative stereotypes that lead to prejudice, discrimination, marginalization and exclusion of Muslims from social, political and civil life". The distinction with other subtypes, such as anti-Semitism $(1.1 \%)$ and Christianophobia (0.2\%), shows a growth in the phenomenon of discrimination against people of Islamic religion or perceived as such. The 2017 report counts 354 cases of discrimination based on religion and personal opinion, and that the highest number of discriminatory behaviors are due to Islamophobia ( $74.3 \%$ of the typology), followed by anti-Semitism (18.9\%).

In any case, since the principle of equality before the law without distinctions of religion also means that no one can escape the application of the law on the basis of their religious affiliation, no one can also avoid complying with the criminal law or believe that they can be acquitted of any crime only because their actions or omissions are based on real or alleged precepts of one's own religion.

In fact, no one can claim as an excuse the ignorance of the criminal law (art. 5 of the Italian Penal Code), except in the case of unavoidable ignorance which, according to the jurisprudence, does not apply for the crimes committed for religious reasons, and therefore the religious factor does not have sufficient relevance with regard to non-liability to punishment.

The Court of Cassation was called upon to assess how relevant the fact of belonging to the Islamic religion was in ascertaining whether all the constituent elements of the crime of family abuse were present. The Court, ${ }^{31}$ after having linked the issue to the cultural offense phenomenon (which is characterized by the conflict between the precepts of culture, of tradition and -at least in the Islamic world- of the law of a particular country, and of those of the host country) notes that, with respect to this conflict, there are two opposing perspectives. The first is the assimilationist one, based on the need for foreign nationals to be incorporated in the legal system of the country of arrival, after having renounced their own ethnic and cultural roots. The other is the integrationist one, oriented towards the preservation of identities, as it is based on the recognition of the coexistence of different cultures as a positive value. In most jurisdictions, such conflict is solved by making both perspectives coexist. In the Italian legal system, alongside the aggravating circumstance envisaged by art. 3, par. 1 of Legislative Decree no. 122/1993 for crimes characterized by

31 Court of Cassation, sentence of 26 November 2008, no. 46300 , with a note by F. Pavesi in Giur.it, 2010, 2, p. 416. 
ethnic, national, racial or religious discrimination and hatred, inspired by the "integrationist" perspective, there are crimes that punish female genital mutilation (art. 583 bis of the Penal Code) and bigamy (art. $55^{6}$ of the Penal Code), which can be considered as expressions of the "assimilationist" logic.

The Court continues by observing that, even for cultural or culturallyoriented crimes, the judge has the duty to simultaneously guarantee the protection of the victims (it is irrelevant whether they consent or not to the infringement of their inalienable rights ${ }^{32}$ ), the respect of the right of the accused to a rigorous verification of the facts and a correct application of the rules, and the delivering of an appropriate verdict for each case. This is because the role of cultural mediator that the doctrine attributes to the criminal judge has to be fulfilled by respecting the rules. In particular, the "integrationist" logic finds a limitation in the respect of the main principles of interpersonal relationships i.e. in the protection of the fundamental and inviolable rights of the person, as imposed by art. 2 and 3 of the Constitution. On the basis of these premises, the Court of Cassation affirmed that the subjective element of the crime of family abuse could not be ruled out by the circumstance that the offender was of Islamic religion and therefore he would claim a particular power as the "head" of the family unit, because such concepts are in absolute contrast with fundamental rules of the Italian legal system.

These considerations have been even more relevant with reference to the issue of what to wear. In this regard, it should be remembered that in personal freedom and in religious freedom, the freedom to decide what to wear is implicit. It can be limited only by law and only when the type of clothing worn or not worn turns out to be against morality, i.e. against the common sense of decency (public indecency), or when clothes make the identity of a person unrecognizable, or when objects that can offend or even weapons are worn as clothing. With regard to the clothes worn by foreigners for religious reasons, the legal questions concerning the Islamic veil and the Sikh kirpan are still not resolved peacefully in the absence of an agreement between the State and the two religious denominations.

In the Italian legal system, the Islamic female veil does not raise any particular problems if it leaves the face uncovered, since every situation in which the woman (Italian or foreign) receives a different treatment only because she wears an Islamic veil is illegal and punishable with an anti-discrimination action. However, the discrimination against women wearing a veil is considered to be legitimate when hiring at a workplace for which not to wear the veil is a 
determinant requirement, ${ }^{33}$ as stated prior to the preliminary selection for employment, or when employers want to connote their business, directly working with the public, in the most neutral way with respect to religion (a question resolved by the European Court of Human Rights by affirming the legitimacy and the reasonableness of this apparent discrimination).

Instead, the use of a full veil preventing the face from being seen (thus not allowing the identification of the person) can be considered as an offence, since it violates the prohibition to use any means to hinder the recognition of the person in a public place, when it happens with no good reason and during events taking place in a public place - an exception is made for sporting events where such use is necessary (art. 5 of law no. 152/1975). Said violation is punishable as a criminal offence not only in cases of willful misconduct, but also for negligence, and it can lead to imprisonment from one to two years or to a fine from 1,000 to 2,000 euros.

The use of the Islamic veil can also be considered as a violation of the prohibition to appear masked in a public place, provided by art. 85 of the Consolidated act of provisions on Public Security and punished with an administrative sanction.

Nonetheless, the jurisprudence rightfully applies such sanctions in a restrictive way. That is both when the veil is temporarily removed for identification purposes and when the not punishable conduct may be carried out to fulfil a religious prescription (even if the Koranic prescription for women is a mere suggestion and does not require a complete obscuration of the face). As said behavior is displayed in order to exercise the constitutional right to freely profess one's religion, it is not sanctioned, as the Penal Code excludes any punishment for those who have committed a crime with the aim to exercise a right.

On the contrary, the administrative and jurisprudential orientation prohibiting the full veil is more severe. Several mayors have taken specific measures, including contingent and urgent ones, to prevent and eliminate serious dangers threatening public safety and urban security (as permitted by art. 54 of Legislative Decree no. 267/2000), which have prohibited the use of the veil (Caravaggion, 2016). In this regard, the Council of State -by rejecting the appeal that had been lodged against a prefectural provision which had quashed an ordinance, issued by a Mayor, that had forbidden the wearing of the veil in a public place- stated that the use of the veil covering the face (the burqa, but especially the hig $\bar{a} b$ ) is not generally aimed at avoiding recognition, as it

33 See Court of Appeal of Milan, labour section, sentence of 20 May 2016, no. 579, commented in L. Pedullà, L'abbigliamento religioso tra identità e compatibilità ordinamentale, in Federalismi.it, no. 24, 2016. 
constitutes the implementation of a tradition of certain peoples and cultures. Consequently, the judge does not have to make value judgments on the mere use of such symbols, but just has to verify whether the veil is worn to prevent recognition without any justifiable reason. Article 5 of law no. 152/1975, observes the Council of State, ${ }^{34}$ allows that "a person wear the veil for religious or cultural reasons, as public safety is ensured by the obligation for such person to remove the veil, if necessary, to be identified", at the request of an authorized public official. Even criminal judges have always acquitted women who had promptly lifted the veil to allow their identification before entering a courtroom..$^{35}$ On the other hand, the resolution no. $\mathrm{x} / 4553$ of 10 December 2015 adopted by the Lombardy Regional Council, which prohibited people with covered faces to enter the main regional buildings, was considered as lawful, as it specified that religious traditions could not represent a valid reason to justify exceptions, pursuant to art. 5 of law no. 152/1975 relating to safety inside the regional buildings. The Court of Milan, in fact, considered the measure to be non-discriminatory because the disadvantage for Muslim women was strictly necessary to ensure identification with public security purposes, which are objectively justified and legitimate.

The ruling of the Court of Milan was criticized by the doctrine, according to which the above-mentioned regional provision does not cause a mere disadvantage but, rather, a serious limitation to some constitutional rights. In fact, since hospitals are regional facilities, as well as the headquarters of the Lombardy public housing agency, a Muslim woman who is wearing the veil finds herself forced to choose between two distinct constitutionally-guaranteed fundamental rights, i.e. religious freedom and the rights to health, assistance and housing (Caravaggion, 2018).

Even the carrying of the kirpan (the ceremonial dagger of the Sikhs) seems to be forbidden, since it infringes the prohibition (provided by art. 4 of law no. 110/1975) to carry, without any justifiable reason, certain types of knifes perceived as offensive weapons. Besides, this issue has been dealt with in different ways, over time - as the jurisprudence shows.

The judges would initially have dismissed such cases, as the Sikhs could use, as a justifiable reason, the right to freely profess their faith. Later on, instead, the Court of Cassation declared the illegitimacy of this conduct, believing that

34 Council of State, Section VI, sentence of 19 June 2008, no. 3076.

35 See Court of Treviso, Office of the Preliminary investigations judge, ordinance of 3 March 2005 and Court of Cremona, sentence of 27 November 2008, on which see G.L. Gatta, Islam, abbigliamento religioso, diritto e processo penale: brevi note a margine di due casi giurisprudenziali, in Stato, Chiese e pluralismo confessionale, June 2009, pag. 3 et seq. 
religious practices should respect the fundamental principles of the Italian legal system, indicated in art. 8 of the Constitution, which includes the protection of people's safety and security ensured by the legislation regulating the use of weapons, and the jurisprudence of the European Court of Human Rights concerning the discretion of the employer to not hire people carrying weapons. The doctrine criticizes these decisions by observing that the limitation within which the fundamental principles of art. 8 of the Constitution can be exercised concerns the internal organization of the various religious confessions - and not the individuals' right to exercise their own freedom of religion, which is limited by art. 19 of the Constitution only in the case of rituals against public morality. Besides, the employer's discretion could lead to paradoxical consequences, as gardeners (for example) could actually carry the kirpan to work, without no intention of showing it in public (ibidem). The State's Relations with the Various Religious Denominations

The Italian Constitution guarantees the freedom of religion not only in its individual dimension, but also in its collective expression through a diversified system of relations between the State and the various religious denominations, in a context of state secularism.

First of all, it is important to note that the Constitution uses the notion of religious denomination, but does not indicate its constituent elements. The issue is essential when it comes to minority religious groups, new groups, groups that are not very well known or that are even secret - and which, because of those characteristics, are sometimes discriminated and persecuted. This is significant also with regard to the religious denominations professed by foreigners forced to leave their own country because of their belonging to sects or to local or new animistic groups. In this regard, doctrine is divided: some demand that every denomination have a normative and organizational structure similar to that of the Catholic Church or other "traditional" Churches (Gismondi, 1975; D'Avack, 1978), while others refer to the autonomous decision of each group to qualify as a religious denomination (Randazzo, 2006).

The Constitutional Court, however, clearly excludes "the unreasonable results of an uncontrollable self-qualification"36 and believes that the confessional nature of a community of faithful can derive from many factors. Some of them are the following: the possible presence of an agreement stipulated with the State, pursuant to art. 8 of the Constitution; previous public recognition,

36 Constitutional Court, sentence no. 467/1992. 
such as the attribution of legal personality to a representative body (on the basis of the law on "accepted cults" of 1929); a statute that clearly expresses its main features; or even the common consideration. ${ }^{37}$ Moreover, in the absence of an agreement with the State, the criteria indicated by the Court, as part of the doctrine believes (Randazzo, 2006), should be considered as a whole, and not as an alternative. This is to avoid putting self-reference first (through the statutory element) or even the State's point of view (through previous public recognition) or, finally, the sociological aspect (through the common consideration element). In particular, the sociological criterion of the "common consideration", suggested by a part of the doctrine (Barillaro, 1968), is difficult to observe when it comes to both new religious movements (whose distinctive features are not yet known by public opinion) and other religious movements that are present in other countries (even though as a minority) and have been brought to Italy by persecuted foreigner nationals.

The self-definition of the religious group must be in line not only with its external characteristics, but also with the animus of its members, i.e. with their willingness to act as an autonomous formation in the pursuit of a religious purpose (Colaianni, 1990). In fact, people who gather under the same religious denomination do so because they embrace a creed that is different from any other - thus organizing themselves within a distinct structure (Long, 1991). They, in fact, have their own specific view of the world, as well as of the relationship with the transcendent - both sustained by an autonomous doctrinal and dogmatic knowledge and by a special organization (which can be minimal, at times, but nevertheless characterized by an independent consistency and a precise identity) (Finocchiaro, 1975; Cardia, 1983; Mirabelli, 2006). However fundamental, the State's evaluation appears to be quite difficult to ascertain. Indeed, it cannot only "acknowledge" the situation, nor can it cast doubts on that doctrinal knowledge (as the Council of State pointed out in opinions relating to the recognition of the legal personality of the Italian Congregation of Jehovah's Witnesses and of the Italian Buddhist Union). Rather, it has to judge the animus of the community by examining the purposes pursued and the organizational structure that has been built (Botta, 1994).

Moreover, the established doctrine accepts the notion according to which a religious denomination is characterized by a community united around the elements of crystallization, development and expression of faith. It differs from other social formations because of its collective identity, anchored in an attitude towards a transcendent dimension (Colaianni, 2000). 
This being clarified, the first constitutional principle concerning the discipline of the public dimension of religions is the distinction between the juridical order of the State and the spiritual and religious order of religious denominations. This principle is derived from both art. 7 of the Constitution, which provides that the State and the Catholic Church are independent and sovereign, each within its own sphere; and from art. 8, which provides that religious denominations other than Catholicism have the right to self-organization according to their own statutes, provided these do not conflict with Italian law.

That principle of distinction between orders has two consequences:

a) the religious, spiritual and doctrinal area, as well as the internal organization of every religious denomination (statutes, indication of religious authorities, management of places of worship, religious activity, and administrative, financial and territorial set of rules) belong only to the religious groups. Public authorities, in fact, have no power of interference, nor can they use the law to impose to the different religious denominations the timing and the methods to adopt their internal rules or even their contents. Public authorities only have to acknowledge the choices freely adopted by every religious denomination;

b) the fundamental principles of the Italian legal system must be respected by all religious denominations, which cannot wish to directly influence the republican legal system itself, nor make their rules prevail over state norms.

The second relevant constitutional principle in the relations between the Italian State and the various religious denominations is the equally important freedom of each religious confession, as provided by art. 8 of the Constitution. It does not mean that all confessions are subjected to the same juridical discipline, but rather that their members can freely profess their beliefs and carry out the respective activities with no limitations other than those provided for by the Constitution and by the laws (Del Giudice, 1964).

As for the theme of religion, religious affiliation is of essence, considering that any kind of discrimination based only on the number of members is "unacceptable"38 as it is the "intensity" 39 of the social reactions that may follow the violation of the rights of the different groups. Since every religious denomination must receive the same juridical treatment, a differentiated treatment is legitimate only if connected to the different needs or organizational peculiarities of a confession and does not derive from a purely discretionary choice of the State.

38 Constitutional Court, sentence no. 440/1995.

39 Constitutional Court, sentence no. 329/1997 and no. 508/2000. 
The third relevant constitutional principle in the relations between the Italian State and the religious denominations is that of bilateralism. The Italian Constitution provides, in fact, for differentiated regimes in the relations between the State and the Catholic Church, and between the State and any other religious denomination, governed by special bilateral agreements.

On the one hand, the relations with the Catholic Church, recognized as independent and sovereign in its order, are regulated by the Lateran Pacts stipulated in 1929, whose amendment agreed by both parties does not require any constitutional revision (art. 7 of the Constitution). Unilateral amendments by the State are allowed, but bilateral ones are preferred. Thus, the agreement revising the Lateran Concordat (signed on 18 February 1984 and approved by law 25 March 1985 no. 121) adapted the rules of the Concordat between State and Church to the republican constitutional system by establishing framework norms on the basis of which other agreements were later concluded. Such agreements focused on the subject of ecclesiastical goods, support of the Catholic clergy, teaching of religion in schools (see also Chapter 21), religious festivities, management of cultural heritage, and ecclesiastical appointments.

However, the relations of the State with any other religious denomination can be regulated by specific agreements that must be approved by law. Today, there are specific laws approving agreements between the Italian State and 12 religious denominations other than the Catholic one. They are the following:

a) the agreement with the Waldensian Church and the subsequent amending agreements (signed on 21 February 1984, 25 January 1993 and 4 April 2007 and respectively approved by law no. 449/1994, no. $409 / 1993$ and no. 68/2009);

b) the agreement with the Union of the Seventh-day Adventist Christian Churches and the subsequent amending agreements (signed on 29 December 1986, 6 November 1996 and 4 April 2007 and respectively approved with law no. 516/1988, no. 637/1996 and no. 67/2009);

c) the agreement with the Assemblies of God in Italy (signed on 29 December 1986 and approved by law no. 517/1988);

d) the agreement with the Union of Italian Jewish Communities and the subsequent modification (signed on 27 February 1987 and 6 November 1996 and respectively approved by law no. 101/1989 and no. 638/1996);

e) the agreement with the Christian Baptist Evangelical Union of Italy and the subsequent modification (signed on 29 March 1993 and on 16 July 2010 and approved respectively by law no. 116/1995 and no. 34/2012);

f) agreement with the Lutheran Evangelical Church in Italy (signed on 20 April 1993 and approved by law no. 520/1995); 
g) agreement with the Sacred Orthodox Archdiocese of Italy and Exarchate for Southern Europe (signed on 4 April 2007 and approved by law no. 126/2012);

h) the agreement with the Church of Jesus Christ of Latter-day Saints (signed on 4 April 2007 and approved by law no. 127/2012);

i) the agreement with the Apostolic Church in Italy (signed on 4 April 2007 and approved by law no. 128/2012);

j) the agreement with the Italian Buddhist Union (signed on 4 April 2007 and approved by law no. 245/2012);

k) the agreement with the Italian Hindu Union (signed on 4 April 2007 and approved by law no. 246/2012);

1) the agreement with the Italian Soka Gakkai Buddhist Institute (signed on 27 June 2015 and approved by law no. 130/2016).

The agreements reached so far have similar contents, including rules concerning:

a) the spiritual assistance in institutions such as the armed forces, health facilities, and prisons;

b) the right of pupils not to attend Catholic religion classes;

c) the recognition of diplomas conferred by institutes of theological studies;

d) the right to freely establish schools of all levels and other educational institutions (guaranteed also by art. 33 of the Constitution);

e) the recognition of the civil effects to marriages celebrated by the ministers of worship of the respective religious denominations;

f) the tax treatment of the various religious denominations and their financial relations with the State, on the model outlined for the Catholic Church by law 20 May 1985, no. 222;

g) the protection of religious buildings and of assets pertaining to the historical and cultural heritage of each religious denomination, as a guarantee of their own cultural identities;

h) the free exercise of one's own ministry by the ministers of worship appointed by the religious denomination;

i) the recognition of the festivities of each religious denomination.

The agreements that have been stipulated so far offer to the other religious denominations similar guarantees and freedoms as the ones conferred to the Catholic Church by the current Concordat of 1984. They concern, for example, the management of the religious denomination, the religious group's full right of internal jurisdiction and regulation, the freedom of communication, as well as the right to provide religious assistance in particular institutions, such as military bases, hospitals and prisons. Besides, they guarantee certain rights 
only to the faithful of certain communities: in particular, the right of Adventists and Jews to sabbatical rest, the right of the Jews to respect specific food prescriptions, and the right of Adventists and Buddhists to conscientious objection to military obligations.

The text of an agreement with the Christian Congregation of Jehovah's Witnesses in Italy was signed twice (on 20 March 2000 and on 4 April 2007), but it was never approved by the two Houses of Parliament, also because in the parliamentary scrutiny some precepts of that religious group were considered to be against some fundamental principles of the Italian legal system. In fact, the draft law for the approval of the new agreement signed in 2014 was finally never presented to the Chambers.

The draft law approving the agreement with the Church of England association (mainly representing the Anglicans) signed on 30 July 2019 has not yet been presented to the Parliament by the Government. Negotiations have also begun for the agreement with the Romanian Orthodox Diocese of Italy.

As for the agreement with the Islamic religious group, proposals of agreement formulated by various Italian Muslim bodies have so far not led to the start of negotiations with the Italian Government, mainly because of the lack of a unified representation of the Islamic denomination and of a legally approved internal statute. In order to promote a process aimed at filling these gaps, since 2008, the Ministers of the Interior have set up study advisory bodies, also composed of representatives of various Italian Islamic organizations and of Muslim experts.

The negotiation of an agreement with the Sikhs appears to be hindered by two opinions of the Council of State, according to which this religious group has rules that contrast with some fundamental principles of the Italian legal system.

Furthermore, the Constitutional Court has clarified that the agreements do not grant additional privileges to the religious denominations that have concluded them, nor do they prevent the religious groups that have not yet stipulated them from exercising their religious freedom. In fact, since the attitude of the State can only be of equality and impartiality towards all religious groups, ${ }^{40}$ these agreements regulate the relations of the various religious denominations with the State as for some specific aspects concerning the individual groups or when exceptions to the ordinary law are needed. Public authorities, in fact, cannot impose such agreements to the different religious groups in order to benefit of the freedom of organization and action guaranteed by the

40 Constitutional Court, sentence no. 508/2000. 
Constitution, nor to make them take advantage of the favorable norms regarding religious denominations. ${ }^{41}$

Therefore, the State can regulate, in a bilateral and differentiated way, its relations with each religious denomination, as provided for by art. 7 and 8 of the Constitution, in order to fulfil specific needs, to grant particular advantages or impose particular limitations, or to give relevance, in its legal system, to specific acts of the religious denomination in consideration. Consequently, it would be a violation of the constitutional principle of the equality of freedom to grant advantages to one religious group if not connected to its specific needs (Onida, 1978).

In any case, state and regional laws cannot "discriminate between religious denominations on the basis of the sole circumstance that they have, or have not, regulated their relations with the State through agreements". Indeed, "religious freedom is one thing, and is guaranteed to everyone without any distinction, while agreements are another", 42 so that the freedom of religion -of which the freedom of worship is an essential part (art. 19 and 20 of the Constitution)cannot be subordinated to the stipulation of agreements with the State. ${ }^{43}$

\section{Religious Freedom with Reference to Family, Education of Minors, Religious Assistance in Prisons}

Numerous practical issues linked to the cohabitation of different religions concern religious aspects that have affected the legal status of foreigners and of asylum seekers. Some issues relate to family formation and to the celebration of marriage. First of all, it must be remembered that religious freedom (art. 19 of the Constitution), the prohibition of discrimination based on religion and gender (art. 3 of the Constitution), the juridical and moral equality of spouses (art. 29 of the Constitution), the right and the duty of both parents to educate their children (art. 30 of the Constitution) are fundamental principles of the Italian legal system. Said principles are incompatible with any rule, in force in other States, preventing the marriage -or imposing the dissolution of a marriage- when the partners have different religion, or one of them refuses to convert to a particular religion, or providing a preferential legal treatment to one spouse (e.g. possibility of polygamous marriage, dissolution of marriage

41 Constitutional Court, sentence no. 346/2002.

42 See Constitutional Court, sentence no. 63/2016, with reference to sentence no. 52/2016.

43 See Constitutional Court, sentence no. 52/2016 and no. 63/2016. 
with unilateral repudiation, exclusive custody of children or exclusive possession of the assets of the other spouse). These rules are against public order, i.e. against the fundamental principles of the Italian legal system, and are therefore inapplicable by the Italian judge -pursuant to art. 16 of law no. 218/1995who has to apply the Italian regulations and not the ones in force in the country of origin.

Moreover, laws on marriage in force in another State have an indirect effect on the Italian legal system as for the impediments to the celebration of marriage. According to art. 116 of the Italian Civil Code, foreigners who want to celebrate their marriage in Italy must possess the permit issued by the competent authority of their country - thus showing that there are no impediments to the celebration of the marriage, according to the law in force in the country of which the foreigner is a national. This obligation causes at least two potentially prejudicial effects on the right of every person to form his own family. People affected by this are the following:

a) The ones who are seeking asylum or have been persecuted cannot obtain this certification from the diplomatic-consular representatives of the State from which they have escaped, also because they would jeopardize the credibility of their application for international protection. According to art. 25 of the 1951 Convention on the status of refugees, this impossibility can be compensated by the Italian diplomatic representation in the foreigner's State, but also -in Italy- by the United Nations High Commissioner for Refugees. ${ }^{44}$

b) Asylum seekers, holders of subsidiary protection, all those who would never obtain the permit - i.e. people who do not have any identification documents, or fear being identified and persecuted, or must obey to a foreign law establishing, as impediment to marriage, the belonging to a specific religious denomination or conviction for crimes linked to the violation of religious norms, the conversion to another religion, and the expression of religious criticism or atheist convictions. For these people, it is possible to appeal to a faculty envisaged by art. 98 of the Italian Civil Code: the Court, at the request of the two people who want to get married and who declare, in compliance the Italian law, that there are no impediments, can lift them from the mandatory marriage publications. Another topic concerns the right to educate one's children according to the dictates of one's religion.

44 See the forms provided by the offices of the UNHCR in Italy to obtain the documentation replacing the marriage permit: https://www.unhcr.it/wp-content/uploads/2018/11/Scheda-NO-new-.pdf. 
In respect of people's personal and religious freedom and of minors' right to health, the above-mentioned right to education is guaranteed by international standards and by the freedom of religion (art. 19 of the Constitution), by the parents' right to educate their children (art. 30 of the Constitution) and by the right to build private schools (art. 33 of the Constitution). The implementation of these rights is ensured both by the rules governing relations between the State and the various religious denominations and by the rules on school equality (see Chapter 21). In particular, art. 1 of law no. 62/2000 provides for a balance between religious needs and constitutional principles: "Private schools are guaranteed full freedom with regard to their cultural orientation and their pedagogical-didactic direction. Independently of the specific educational project of the single schools, teaching has to be based on the principles of freedom established by the Constitution. Private schools carry out a public service, as they welcome everyone who accepts their educational project, including pupils and students with disabilities. The educational project of the school has a precise cultural or religious view. However, extra-curricular activities that require the adherence to a specific ideology or to a specific religious denomination are not compulsory for any student".

As far as religious and family matters are concerned, the contrast between foreign laws and the fundamental principles of the Italian legal system has manifested itself also in relation to other themes, relevant for the life of all foreigners in Italy, including asylum seekers, i.e. the care of children and the dissolution of marriage.

With reference to the responsibility of the parents, the Court of Cassation ${ }^{45}$ stated that, in deciding on the custody of children in case of separation of the parents, the Italian judge cannot apply the Iranian law (national law of the father), which allows the father to gain the exclusive custody of the children, since such law is inapplicable in the Italian system, due to the aforementioned limit represented by public order. This criterion is different from that set by art. 155, par. 1 of the Italian Civil Code, by virtue of which decisions relating to children must be adopted with exclusive reference to the moral and material interest of the minors. Independently of the actual ability of the parent to take care of one's offspring, the Iranian law clearly contrasts with the gender discrimination prohibition (art. 3 and 29 of the Constitution) and with the principle of secularism - which does not allow to use the religious belief of the parents as a criterion for choosing the foster parent.

As for the foreigners' right to family unity, the Court of Cassation has stated that the foreign parent can request the reunification with his/her dependent 
children (according to art. 29 of Legislative Decree no. 286/1998) if he/she is able to financially support them. However, in doing so, said parent does not also gain the -exclusive or concurrent- parental responsibility of minors. On this topic, it is worth mentioning a case relating to a Moroccan citizen who was repudiated by her husband in accordance with the Moroccan law and was denied the legal protection of her children, as requested by her husband. Under such circumstances, she could ask for reunification with her children only on condition that she provided them with a suitable accommodation in the Italian territory and that she earned a sufficient income to satisfy this requirement.

Every foreign minor in Italy is subject to compulsory schooling under the same conditions as Italian citizens (art. 38 of Legislative Decree no. 286/1998). Thus, another issue concerning the religious education of foreigners, including asylum seekers, is that of religious education in public schools.

Art. 9 of the 1984 Amendment Agreement of the Concordat between the State and the Holy See, affirms that the State, "recognizing the value of religious culture and considering that the principles of Catholicism are part of the historical heritage of the Italian people, continues to ensure, within the framework of school aims, the teaching of the Catholic religion in educational institutions of all types and at all levels". However, it leaves it up to either the students -if aged 14 or over- or their parents to decide whether to attend such classes. Therefore, the teaching of Catholic religion in public schools involves a faculty that the parents (or the students who are 14 years old or older) express at the beginning of the school year. And that even if the teachers of Catholic religion are paid by the State and their grading is an integral part of the student's overall scholastic evaluation. Besides, alternative educational activities must be provided for those who do not attend those classes. The Constitutional Court has specified that it is no "obligation" and that, for this reason, the school workload cannot increase for those who choose not to participate. In fact, alternative activities cannot be made compulsory - otherwise, a primary subjective right is violated, thus causing a compensable damage. ${ }^{46}$ Besides, class schedule must be organized in such a way as to avoid any discrimination, even if said class does not necessarily have to be placed in the first or in the last hour of the school day, since the characteristic of non-obligation may also include the choice to leave the school during that hour. ${ }^{47}$

In addition, as stated in the agreements with the religious denominations other than the Catholic one, each religious group has the right to respond to any requests made by the students, their families and the schools, as far as the

46 Court of Cassation, united civil section, no. 11432/1997.

47 Constitutional Court, sentence no. 13/1991. 
study of the religious facts and their implications are concerned. However, it must be noted the lengthy jurisprudential controversy concerning the exposition of the crucifix in the classrooms. Some wanted to have it removed from the walls of the Italian public schools because, as a symbol of a religious group, it was considered an instrument of religious propaganda incompatible with the secular state and potentially offensive for atheists and for those belonging to other religious denominations. With regard to the exhibition of the crucifix in public places (classrooms, courts of justice, electoral offices), the jurisprudence has expressed conflicting orientations. In fact, some have deemed the obligation to be no longer in force, having been provided by secondary rules that have been introduced during the fascist regime in a constitutional system that used to consider the Catholic religion as the religion of State, and are now incompatible with the current constitutional and international norms. ${ }^{48}$ Others have affirmed that it cannot offend anyone since it is not the religious symbol of a religious group, but rather a symbol of the historical roots of the Italian people, which expresses "the religious origin of the values of tolerance, mutual respect, enhancement of the persons, promotion of their rights, of their freedom, of the autonomy of their moral conscience towards the authority, of human solidarity, and of rejection of all discriminations. All of this characterizes the Italian civilization". Therefore, the exposition of the crucifix evokes values that "emerge from the fundamental norms of our Charter and, specifically, from the ones mentioned by the Constitutional Court about the secular nature of the Italian State". ${ }^{49}$ Besides, some other, by basing on the principle of

48 Court of Cassation, criminal Sction IV, no. 439/200o. It stated that the rules on the display of the crucifix should implicitly be understood as repealed due to their religious domination matrix, also because the presence of this symbol in classrooms used as polling stations would risk causing "a serious disturbance to one's conscience" and its imposition, as linked to the symbolic value of an entire civilization or of the collective ethical conscience, would go against the "clear prohibition" imposed in this matter by the principle of equality referred to in art. 3 of the Constitution.

49 Council of State, Section VI, sentence no. 556/2006 and Council of State, Section II, opinion of 15 February 2006 (issued in the extraordinary appeal to the Head of State proposed by the Union of atheists, agnostics and rationalists against the directive of 3 October 2002 by the Ministry of Education on the display of the crucifix in classrooms). In this opinion, it is admitted that, today, the crucifix "must also be seen as a religious symbol", and common to several denominations (all Christian ones). However, it would be "in opposition to the very origins of our Constitution, as well as to the sentiment of our people, to exclude a Christian sign from a public structure in the name of secularism, which also finds one of its distant sources in the Christian religion". Nor could the subjective right of religious freedom be invoked, because its "protection cannot be extended to the psychological sphere, that is, to the dimensions of individual conscience and feelings, which would lead 
autonomy of each scholastic institution provided by the Constitution, believe that all classes should decide for themselves.

Finally, the religious dimension of foreigners, including asylum seekers, is especially relevant for people inside Italian prisons (in which there are many foreigners). Prisoners must be treated with humanity and respect for the dignity of the person, with absolute impartiality, without discrimination as regards gender, sexual orientation, race, nationality, economic and social conditions, political opinions and religious beliefs, and must follow models that favor autonomy, responsibility, socialization and integration (art. 1 of law 26 July 1975, no. 354).

Furthermore, penitentiary institutions must be equipped with rooms that are suitable for the needs of the prisoners' individual life and, if possible, rooms to carry out religious activities (art. 5 of law no. 354/1975). Prisoners must be guaranteed a diet that respects their religious beliefs (art. 9 of law no. 354/1975), so that in deciding the food to administer to prisoners, which must be approved by a decree of the Minister of Justice, the prescriptions of the different religious faiths must be taken into account (art. 11 of Presidential Decree no. 230/2000).

More generally, prisoners' treatment also involves religion (art. 15 of law no. 354/1975). Indeed, prisoners have the freedom to profess their religious faith and to practice its worship. In penitentiary institutions, the celebration of Catholic rites is guaranteed and at least one Catholic chaplain is assigned to each institute. Prisoners following a religion other than the Catholic one have the right to receive, at their request, the assistance of ministers of their own religious denomination and celebrate their rites (art. 26 of law no. 354/1975). Prisoners, in fact, have the right to participate in the rites of their religious group, provided they are compatible with the security of the institution and not contrary to the law, according to the provisions of art. 58 of Presidential decree no. 230/2000:

a) prisoners have the right to display, in their room, images and symbols of their own religion;

b) during free time, prisoners are allowed to practice their religions, provided that they do not engage in dangerous acts for the community;

c) in order to celebrate Catholic rites, each institute has one or more chapels, according to the requirements of the religious service;

to the recognition of a right to a sterile environment, in which we are all preserved from receiving messages against personal sentiments". 
d) for religious education and for the practices of worship by members of other religious denominations, even when in the absence of ministers, the institute's management offers suitable spaces.

The institute's management, in order to guarantee to prisoners religious education and spiritual assistance, as well as the celebration of the rites of other confessions, arranges for the ministers of worship requested by the different religious groups, and always indicated by the Ministry of the Interior, to perform their duties inside the prisons. Finally, the daytime isolation of prisoners sentenced to life does not exclude their admission to religious services (art. 73 of Presidential decree no. 230/200o).

In the 2019 Report to Parliament, the National Defender for the rights of persons whose personal freedom has been restricted has recommended the Government (so far, without any implementation) to promote in "high security" prisons, thanks to specific scientific competences, projects and programs of de-radicalization of the people who have been sentenced for crimes aggravated by the terrorist aim of the so-called religious fundamentalism.

The rules examined so far make us understand why from the principle of equality for any religion (art. 3 of the Constitution), from religious freedom (art. 19 of the Constitution), from the prohibition of special burdens for religious bodies (art. 20 of the Constitution), from the equal freedom of every religious group before the law and from their full freedom of internal organization (art. 7 and 8 of the Constitution), the Constitutional Court has deduced that the Italian legal system is characterized by the principle of state secularity, meant not as indifference of the State towards the religious experience, but rather as the protection of pluralism, in support of the maximum expansion of freedom for all, according to criteria of impartiality.

In this regard, some doctrine (D'Amico, 2008) has developed a method that can be defined as "secular" to resolve conflicts between opposing and apparently irreconcilable rights, which is the resort to constitutional principles. Fundamental aspects of this method are:

a) the involvement of different institutional actors, i.e. the legislator, the Constitutional Court, the common judges and the citizens, since there is not one unique way to defend the rights;

b) the rejection of laws that attempt to "moralize" by imposing "values";

c) the acquisition by the institutional actors of the scientific data and their attention to reality, to be taken into consideration in an objective manner;

d) attention towards the respect for the rights of minorities, especially if they are "weak". And, of course, these weak minorities include asylum seekers for religious reasons. 